\title{
Characterization of Patinas that Formed on Copper Exposed in Different Environments for One Month
}

\author{
Masamitsu Watanabe*, Takao Handa*, Toshihiro Ichino**, \\ Nobuo Kuwaki* and Jun'ichi Sakai*** \\ * Technical Assistance and Support Center, Nippon Telegraph and Telephone East Corporation \\ ** NTT Energy and Environment Systems Laboratories, Nippon Telegraph and Telephone Corporation \\ *** Department of Materials Science and Engineering, Waseda University
}

\begin{abstract}
The early stage of copper patination, which occurs when copper is exposed to the atmosphere, was investigated by exposing copper plates for one month in urban, rural/coastal, hot springs, suburban, and volcanic areas. The exposures experiment started in summer or autumn. The patinas that formed during the one-month exposure were characterized using X-ray diffraction (XRD), X-ray fluorescence analysis, X-ray photoelectron spectroscopy (XPS), scanning electron microscopy (SEM), and glow discharge optical emission spectroscopy (GDOES). The XRD patterns revealed that cuprite $\left(\mathrm{Cu}_{2} \mathrm{O}\right)$ and posnjakite $\left(\mathrm{Cu}_{4} \mathrm{SO}_{4}(\mathrm{OH})_{6} \cdot \mathrm{H}_{2} \mathrm{O}\right)$ formed on the copper exposed in all areas, except the hot springs area. This is the first report of posnjakite forming on copper exposed for one month in benign environments. The XRD pattern revealed only cuprite on the copper exposed in the hot springs area although copper sulfide $\left(\mathrm{Cu}_{2} \mathrm{~S}\right)$ was found in the cathodic reduction curve. The sulfur $2 \mathrm{p}$ XPS spectra of copper exposed in the urban, rural/coastal, and volcanic areas mainly showed a sulfate component, whereas that of copper exposed in the hot springs area showed both sulfide and sulfate components. The former reflected the formation of posnjakite; the latter reflected the oxidation of sulfide during exposure. In contrast, the chlorine $2 \mathrm{p}$ XPS spectra revealed that the chlorine existed as chloride. The SEM observation revealed that the surface morphology differed between exposure sites. GDOES depth profiling analysis revealed a difference in the distributions of sulfur and chlorine in the early stage of copper patination. The sulfur was located in the upper part of the patina, whereas the chlorine penetrated the patina. The oxidized sulfur species lowered the $\mathrm{pH}$ of the surface electrolyte, and this accelerated the dissolution of cuprite. They also formed posnjakite, which roughened the surface. The reduced sulfur species lowered the $\mathrm{pH}$ of the surface electrolyte and formed copper sulfide. The chlorine dissolved the cuprite forming copper chloride complex. This changed the chlorine depth profile.
\end{abstract}

Key words : copper, atmospheric corrosion, physical analysis, sulfur, chlorine

\section{Introduction}

Copper is commonly used in electronic applications because of its good electrical and thermal properties. However, electronic parts and devices sometimes suffer severe damage due to atmospheric corrosion of the copper, particularly in the presence of corrosive gases and particles. The demand for smaller and more compact electronic parts and devices reduces their reliability against corrosion. That is, even slight corrosion can cause them to fail. ${ }^{1-3)}$ Much of our telecommunication equipment, comprising many electronic parts and devices, is now installed and used in the outdoor shelters. As atmospheric corrosion is a constant threat to their reliability, we need to understand the corrosion behavior of copper exposed to the atmosphere, particularly its early stages.

Generally, atmospheric corrosion of copper is governed by the relative humidity and corrosive species including gases and particles. To understand the corrosion behavior of copper, laboratory chamber tests using corrosive gases such as sulfur dioxide $\left(\mathrm{SO}_{2}\right)$ under humid conditions have been conducted. ${ }^{4}{ }^{-6)}$ Rickett et al. reported that cuprite $\left(\mathrm{Cu}_{2} \mathrm{O}\right)$ mainly formed with a small amount of sulfide on

* 4-10-23, Higashigotanda, Shinagawa-ku, Tokyo, 141-0022 Japan

** 3-9-11, Midori-cho, Musashino-shi, Tokyo, 180-8585 Japan

*** 3-4-1, Okubo, Shinjuku-ku, Tokyo, 169-8555 Japan copper exposed in $75 \mathrm{ppb} \mathrm{SO}_{2}$ at $23^{\circ} \mathrm{C}$ and $70 \%$ relative humidity (RH). ${ }^{4)}$ They also reported that the addition of nitrogen dioxide $\left(\mathrm{NO}_{2}\right)$ accelerated copper corrosion and that cuprite and $\mathrm{CuO}$ with $\mathrm{Cu}(\mathrm{OH})_{2}$ were found on the exposed copper. Ericsson et al. reported the formation of corrosion products on copper exposed in 10 and $100 \mathrm{ppm}$ $\mathrm{SO}_{2}$ at $22^{\circ} \mathrm{C}$ with high $\mathrm{RH}(90$ and $97 \%){ }^{5)}$ They found hydrated copper sulfate $\left(\mathrm{CuSO}_{4} \cdot 5 \mathrm{H}_{2} \mathrm{O}\right)$ and Chevreul' $\mathrm{s}$ salt $\left(\mathrm{CuSO}_{3} \mathrm{Cu}_{2} \mathrm{SO}_{3} \cdot 2 \mathrm{H}_{2} \mathrm{O}\right)$. Persson et al. showed that cuprite and copper sulfite formed on copper exposed in $0.21 \mathrm{ppm} \mathrm{SO}_{2}$ at $80 \% \mathrm{RH}$ using infrared reflection absorption spectroscopy. ${ }^{6)}$ However, corrosion products observed in a test chamber differ from those found in actual outdoor environments. As pointed out by Lobnig et al. ${ }^{7), 8)}$, the contribution of fine particulate sulfates such as ammonium sulfate $\left(\left(\mathrm{NH}_{4}\right)_{2} \mathrm{SO}_{4}\right)$ have to be taken into consideration when investigating the formation of copper patinas.

Copper patinas formed in actual outdoor environments have been analyzed. Nassau et al. analyzed copper roofs at AT\&T Bell Laboratories and a portion of the Statue of Liberty and reported the presence of cuprite, brochantite $\left(\mathrm{Cu}_{4} \mathrm{SO}_{4}(\mathrm{OH})_{6}\right)$, antlerite $\left(\mathrm{Cu}_{3} \mathrm{SO}_{4}(\mathrm{OH})_{4}\right)$, posnjakite $\left(\mathrm{Cu}_{4} \mathrm{SO}_{4}(\mathrm{OH})_{6} \cdot \mathrm{H}_{2} \mathrm{O}\right)$, and atacamite $\left(\mathrm{Cu}_{2} \mathrm{Cl}(\mathrm{OH})_{3}\right)$ in natural patinas. ${ }^{9)}$ Nairn et al. showed that posnjakite and brochantite formed during exposure of three months or more in an industrial area. ${ }^{10)}$ They also discovered that it takes about one year for posnjakite to form in an urban area. Although analytical results for copper patinas formed 
during long exposures such as a year or more have been reported, little attention has been paid to copper patinas formed during short exposures. To understand the initial stage of atmospheric copper corrosion, we need to understand the chemical properties of natural patinas formed during short periods.

As described above, there have been many studies of copper patination for long exposure time but few for short exposure times. We have investigated and analyzed patinas formed on copper exposed for one month in different environments using several analytical techniques. ${ }^{11)-17)} \mathrm{We}$ identified crystalline phases in the patinas by X-ray diffraction (XRD) and quantified the amounts of sulfur and chlorine in the patinas by X-ray fluorescence analysis (XRF). We used X-ray photoelectron spectroscopy (XPS) to analyze the chemical states and scanning electron microscopy (SEM) to observe the surfaces. We used glow discharge optical emission spectroscopy (GDOES) to profile the depth of the elements constituting the patinas. Using our analytical results, we identified the roles of sulfur and chlorine in the early stage of copper patination.

\section{Experimental}

\subsection{Exposure}

The copper plates we used were $99.9 \%$ pure and $42 \times$ $25 \times 0.2 \mathrm{~mm}$ in size. Before exposure, their surfaces were cleaned with acetone and nitric acid.

Plates were exposed outside our telephone switching centers located in urban, rural/coastal, hot springs, and volcanic areas. ${ }^{11)}$,15) They were hung vertically under the eaves of the centers to reduce the effect of rainfall. Plates were also exposed in a suburban area, the grounds of our laboratory. They were hung in a small shelter, $50 \times 25 \times 15$ $\mathrm{cm}$, with 21 ventilators to enable outside air to circulate through the interior. ${ }^{17)}$ The exposure periods were one month except for the volcanic area, which was set to 22 days to fit the maintenance period. For simplicity, the plates exposed in the urban, rural/coastal, hot springs, suburban, and volcanic areas are referred to as samples A, $\mathrm{B}, \mathrm{C}, \mathrm{D}$, and $\mathrm{E}$, respectively. The average temperature and relative humidity during exposure are summarized in Table 1.

\subsection{Analysis}

After exposure, we analyzed the patinas that formed on

Table 1 Average temperature and relative humidity during exposure.

\begin{tabular}{ccccc}
\hline Sample & Location & $\begin{array}{c}\text { Exposure } \\
\text { period }\end{array}$ & $\begin{array}{c}\text { Average } \\
\text { temp. }\left({ }^{\circ} \mathrm{C}\right)\end{array}$ & $\begin{array}{c}\text { Average } \\
\mathrm{RH}(\%)\end{array}$ \\
\hline A & Urban & Jun. to Jul. & 24.4 & 65 \\
B & Rural/coastal & Jun. to Jul. & 23.1 & 87 \\
C & Hot springs & Jul. to Aug. & 16.9 & 88 \\
D & Suburban & Sep. to Oct. & 18.4 & 70 \\
E & Volcanic & Sep. to Oct. (22days) & 23.2 & 81 \\
\hline
\end{tabular}

copper plates using several analytical techniques.

We used XRD to identify the crystalline phases in the patinas. A Rigaku RU 200 diffractometer was used with $\mathrm{Cu}$ $\mathrm{K} \alpha$ radiation. The X-ray source was operated at $50 \mathrm{kV}$ and $200 \mathrm{~mA}$.

We used XRF to determine the amounts of sulfur and chlorine in the patinas. A Rigaku 3063P X-ray fluorescence analyzer was used to analyze samples A, B, and C. The tube voltage was $50 \mathrm{kV}$, and the current was $30 \mathrm{~mA}$. A Rigaku 3270 X-ray fluorescence analyzer was used to analyze sample $\mathrm{D}$. The tube voltage was $50 \mathrm{kV}$, and the current was $50 \mathrm{~mA}$. A Shimazu XRF-1800 X-ray fluorescence analyzer was used to analyze sample $\mathrm{E}$. The tube voltage was $40 \mathrm{kV}$, and the current was $80 \mathrm{~mA}$. Standard thin films of copper sulfide $(\mathrm{CuS})$ and potassium chloride $(\mathrm{KCl})$ were used to quantify the sulfur and chlorine, respectively.

We used XPS to analyze the chemical state of the patinated surfaces of samples A, B, C, and E. The surface of an unexposed copper plate was also analyzed for comparative purposes. The XPS analysis was performed using a PHI model XPS 5700. A monochromated Al K $\alpha$ X-ray source with a characteristic energy of $1486.6 \mathrm{eV}$ was used. The Xray source was operated at a total power dissipation of 200 $\mathrm{W}$. We analyzed an area $800 \mu \mathrm{m}$ in diameter. We recorded survey scans and detailed scans of the $\mathrm{Cu} 2 \mathrm{p}, \mathrm{Cu}$ LMM Auger, O 1s, S 2p, Cl 2p, N 1s, and C 1s regions in $0.1 \mathrm{eV}$ energy steps. The spectra were collected at a $45^{\circ}$ photoelectron takeoff angle. The binding energies were corrected using the energy value for the carbon contamination peak at $284.6 \mathrm{eV}$.

We used SEM to observe the morphology of the corroded surfaces. A JEOL JSM-890 system was used at an acceleration voltage of $3 \mathrm{kV}$. The sample surface was coated with platinum, less than $10 \mathrm{~nm}$ thick, to prevent charge-up effects.

We used GDOES to analyze the elemental distribution in the patinas. A Jobin Yvon N-5000RF was used with an applied frequency and power of $13.56 \mathrm{MHz}$ and $40 \mathrm{~W}$, respectively. The Ar pressure was $775 \mathrm{~Pa}$, and the analysis area was $4 \mathrm{~mm}$ in diameter. The relationship between the sputtering time and depth was established by using GDOES analysis to measure the depth of the craters that formed during the sputtering.

\section{Results and Discussion}

\subsection{Phase identification by XRD}

Fig. 1 shows the XRD patterns for samples A, B, C, D, and E. As seen in Fig. 1, cuprite and posnjakite were found on samples A, B, D, and E, while only cuprite, a primary corrosion product on copper ${ }^{9)}$ was observed on sample C. Cuprite was commonly found on all samples. Posnjakite has been reported to form in the early stage of copper patination. ${ }^{9,10), 18)}$ Nassau et al. reported the formation of posnjakite on copper exposed for one year and that its X-ray intensity weakened with further exposure. ${ }^{9)}$ They also 


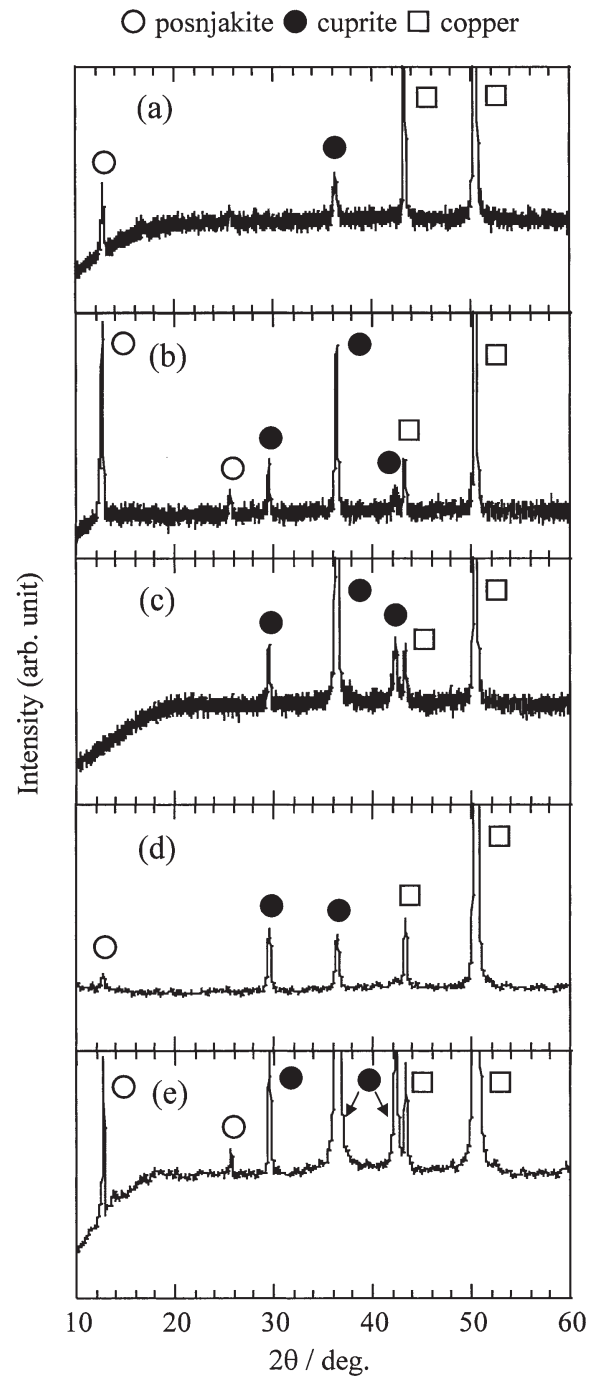

Fig. 1 XRD patterns of copper plates exposed to various atmospheres : (a) urban area, (b) rural/coastal area, (c) hot springs area, (d) suburban area, and (e) volcanic area.

found that posnjakite acts as a precursor of brochantite, which is commonly found in natural patinas formed during long exposures. Nairn et al. showed that posnjakite formed within ten days of exposure in an industrial area, while it took a year for it to form in an urban area. ${ }^{10)}$ Odnevall et al. reported that the formation of posnjakite on copper exposed in a rural area. ${ }^{18)}$ They suggested that there is an intermediate non-crystalline phase consisting of copper, sulfur, and oxygen prior to posnjakite formation. Our results clearly showed that cuprite and posnjakite formed in copper patinas on copper exposed in various environments except for a hot springs area. This is the first report of posnjakite forming on copper exposed for one month in benign environments (urban and suburban areas). It is worth noting that there is a threshold amount of sulfur on copper for posnjakite formation : $0.4 \mu \mathrm{g} / \mathrm{cm}^{2}{ }^{19}$ )

As shown in Fig. 1(c), only cuprite was found in the $\mathrm{XRD}$ pattern for the sample $\mathrm{C}$, the sample exposed in a hot springs area, where there was hydrogen sulfide $\left(\mathrm{H}_{2} \mathrm{~S}\right)$ in the air. The average $\mathrm{H}_{2} \mathrm{~S}$ concentration during exposure was 13 ppb. ${ }^{12)}$ As will be shown later, sample $\mathrm{C}$ had the largest amount of sulfur. Fig. 2 shows the cathodic reduction curve for sample $\mathrm{C}^{12}{ }^{12}$ The reduction was carried out in a deaerated $0.1 \mathrm{M} \mathrm{Na}_{2} \mathrm{CO}_{3}$ solution. The $\mathrm{Ag} / \mathrm{AgCl}$ electrode was used as a reference electrode. The temperature and constant current density were set at $25^{\circ} \mathrm{C}$ and $100 \mu \mathrm{A} /$ $\mathrm{cm}^{2}$, respectively. As seen in Fig. 2, there were three reduction plateaus in the curve. We assigned plateaus $\mathrm{A}, \mathrm{B}$, and $\mathrm{C}$ to cuprite, $\mathrm{CuS}$ (or cupric species), and $\mathrm{Cu}_{2} \mathrm{~S}$, respectively. ${ }^{12)}$ Although we did not detect any sulfide phase in the XRD pattern, the existence of $\mathrm{Cu}_{2} \mathrm{~S}$ was revealed by the cathodic reduction. A microstructural analysis using transmission electron microscopy and electron diffraction revealed that there was a non-crystalline phase containing sulfur in sample C. ${ }^{12)}$ This explains the absence of a crystalline sulfide phase in the XRD pattern.

A chlorine-containing phase such as atacamite and nantokite $(\mathrm{CuCl})$ was not detected in the XRD patterns for the five samples. A possible reason for this is the slow formation rate of chlorine-containing phases. Alternatively, the amount of chlorine on the copper was insufficient to form these phases. Fonseca et al. reported that basic copper chloride paratacamite $\left(\mathrm{Cu}_{2} \mathrm{Cl}(\mathrm{OH})_{3}\right)$ formed on copper exposed in a maritime environment for two months. ${ }^{20)}$ This indicates that the chlorine-containing phase can form in an atmosphere in which high amounts of sea-salt aerosol deposits on the copper surface. A previous suburban experiment showed that nantokite forms on copper exposed for one year. ${ }^{17)}$ We believe that chlorine was present as chloride ions or copper chloride complexes in the copper patina and/or adsorbed water layer on the copper before crystalline phase formation.

\subsection{Amounts of sulfur and chlorine determined by $\mathrm{XRF}$}

Table 2 summarizes the amounts of sulfur and chlorine on the plates as determined by XRF. The amounts for sample $\mathrm{E}$ are raw data (22 days of exposure). The amount of sulfur for sample $\mathrm{C}$ was the largest by a significant degree,

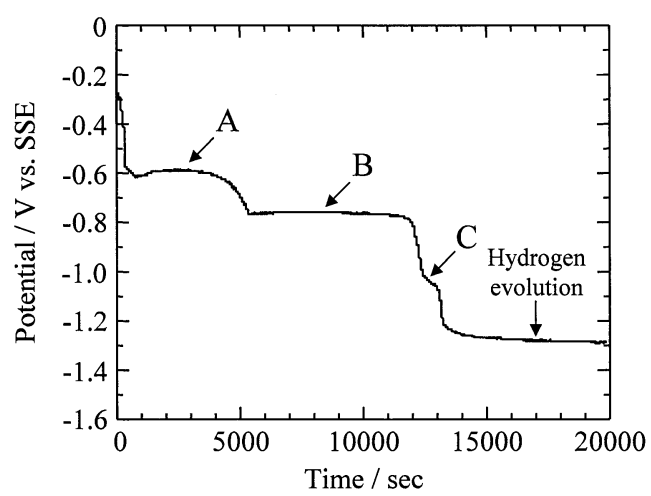

Fig. 2 Cathodic reduction curve for sample C ; plateaus A, B, and C correspond to cuprite, CuS (or cupric species), and $\mathrm{Cu}_{2} \mathrm{~S}$, respectively. [Reproduced with permission from $J$. Electrochem. Soc., 149, B97 (2002), Copyright 2002, The Electrochemical Society.] 
Table 2 Amounts of sulfur and chlorine on copper plates as determined by XRF.

\begin{tabular}{cccc}
\hline Sample & Location & $\begin{array}{c}\text { Sulfur } \\
\left(\mu \mathrm{g} / \mathrm{cm}^{2}\right)\end{array}$ & $\begin{array}{c}\text { Chlorine } \\
\left(\mu \mathrm{g} / \mathrm{cm}^{2}\right)\end{array}$ \\
\hline A & Urban & 1.18 & 3.83 \\
B & Rural/coastal & 3.78 & 2.25 \\
C & Hot springs & 15.46 & 0.13 \\
D & Suburban & 0.39 & 0.68 \\
E & Volcanic & 1.98 & 1.93 \\
\hline
\end{tabular}

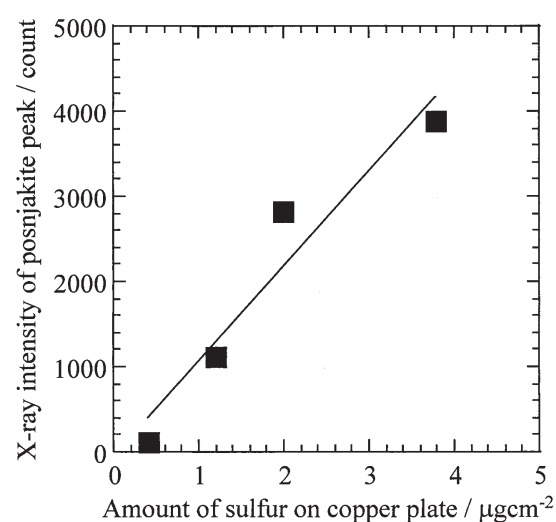

Fig. 3 Relationship between X-ray intensity of the posnjakite peak in the XRD pattern and amount of sulfur on copper plate.

which is understandable given that the exposure site was a hot springs area. Although there was $\mathrm{SO}_{2}$ and $\mathrm{H}_{2} \mathrm{~S}$ in the volcanic area, the amount of sulfur on sample $\mathrm{E}$ was relatively small. This is attributed to the prevailing wind. ${ }^{16)}$

As mentioned, the formation of posnjakite was observed on samples A, B, D, and E. Fig. 3 shows the relationship between the X-ray intensity of the posnjakite (001) peak at about $12.7^{\circ}$ and the amount of sulfur on the copper plate. The straight line represents the least squares fitting and shows that there is a good correlation. This means that sulfur is consumed in the formation of posnjakite.

The largest amount of chlorine was on sample A even though the exposure site was about $10 \mathrm{~km}$ from the seashore, much further from the seashore than the exposure sites for samples B and E. This surprisingly large amount was evidently due to the prevailing wind transporting sea-salt aerosol to the site during the exposure period. ${ }^{14)}$

\subsection{Chemical state analysis by XPS}

Fig. 4 shows detailed XPS scans of the $\mathrm{Cu} 2 \mathrm{p}$ regions of unexposed and exposed copper plates. Sharp doublet peaks originating from $\mathrm{Cu} 2 \mathrm{p}_{3 / 2}$ and $\mathrm{Cu} 2 \mathrm{p}_{1 / 2}$ can be seen in the unexposed copper (Fig. 4 (a)). The peak position of $\mathrm{Cu}$ $2 \mathrm{p}_{3 / 2}$ was $932.6 \mathrm{eV}$, and it is assigned to both metallic copper $\left(\mathrm{Cu}^{0}\right)$ and cuprous species $\left(\mathrm{Cu}^{+}\right){ }^{4)}$ The $\mathrm{Cu} 2 \mathrm{p}$ regions of samples A, B, C, and E were remarkably different from that of the unexposed copper. They featured broader $\mathrm{Cu}$ $2 \mathrm{p}_{3 / 2}$ and $\mathrm{Cu} 2 \mathrm{p}_{1 / 2}$ peaks and satellite peaks on the higher binding energy side. These features are attributed to the presence of cupric species $\left(\mathrm{Cu}^{2+}\right)^{4}{ }^{4},{ }^{21)}$ As shown in the XRD patterns for samples A, B, and E, posnjakite was observed as a cupric compound. Therefore, the XPS results agree well with the XRD results. Although posnjakite was not found on sample $\mathrm{C}$, the $\mathrm{Cu} 2 \mathrm{p}$ spectra were almost the same as those for the other samples. This is explained by the surface oxidation during exposure. Thus, the change in the $\mathrm{Cu} 2 \mathrm{p}$ spectra was due to both posnjakite formation and surface oxidation.

Fig. 5 shows detailed XPS scans of the Cu LMM Auger regions. The spectra for the unexposed copper (Fig. 5(a)) show two peaks at 916.8 and $918.4 \mathrm{eV}$ (kinetic energy unit). Chawla et al. reported that the kinetic energies of the peaks in the $\mathrm{Cu}$ LMM region of copper and cuprite are 918.8 and $917.2 \mathrm{eV}$, respectively. ${ }^{21)}$ Therefore, we can assign the peaks at 916.8 and $918.4 \mathrm{eV}$ to cuprite and metallic copper, respectively. Although copper and cuprite cannot be distinguished in the $\mathrm{Cu} 2 \mathrm{p}$ spectra, the $\mathrm{Cu} \mathrm{LMM}$ Auger spectra clearly showed the presence of two species on the unexposed copper surface. It is well known that a copper surface oxidizes rapidly and that a thin film of cuprite forms even on just-cleaned surfaces. The $\mathrm{Cu}$ LMM Auger spectra for samples A, B, C, and E are similar. There
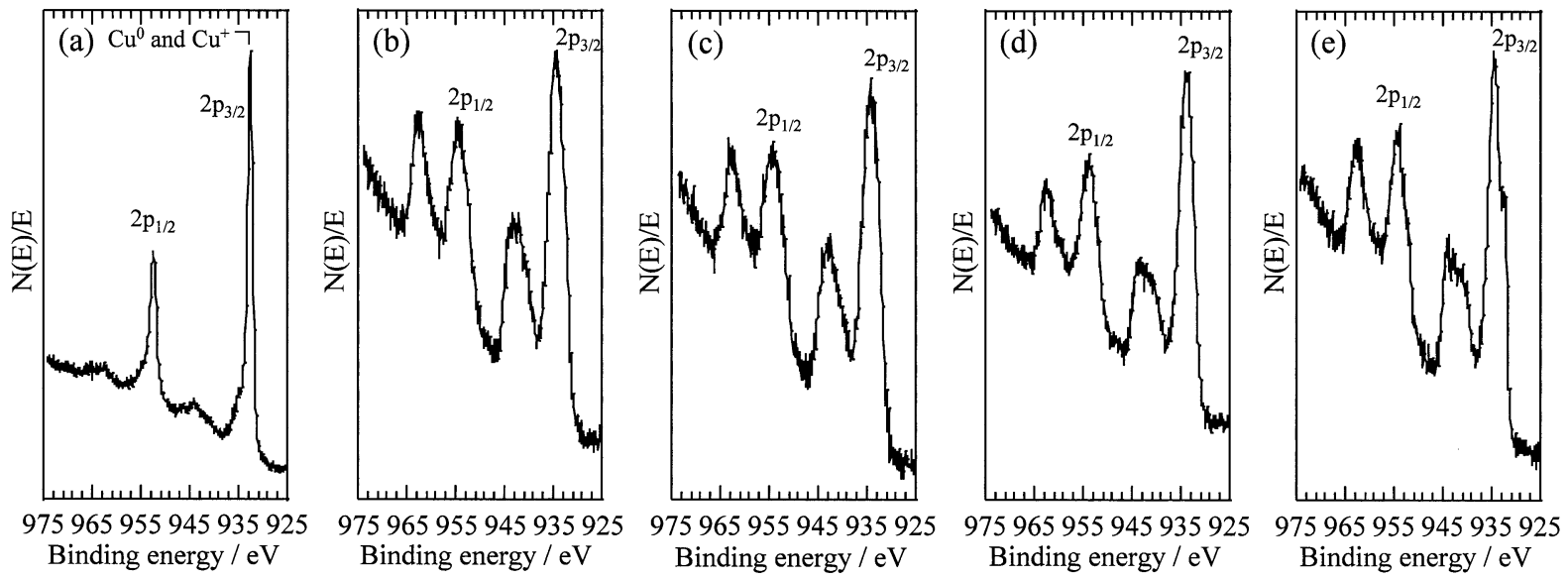

Fig. 4 Detailed XPS scans of $\mathrm{Cu} 2 \mathrm{p}$ region: (a) unexposed, (b) sample A, (c) sample B, (d) sample C, and (e) sample E. 

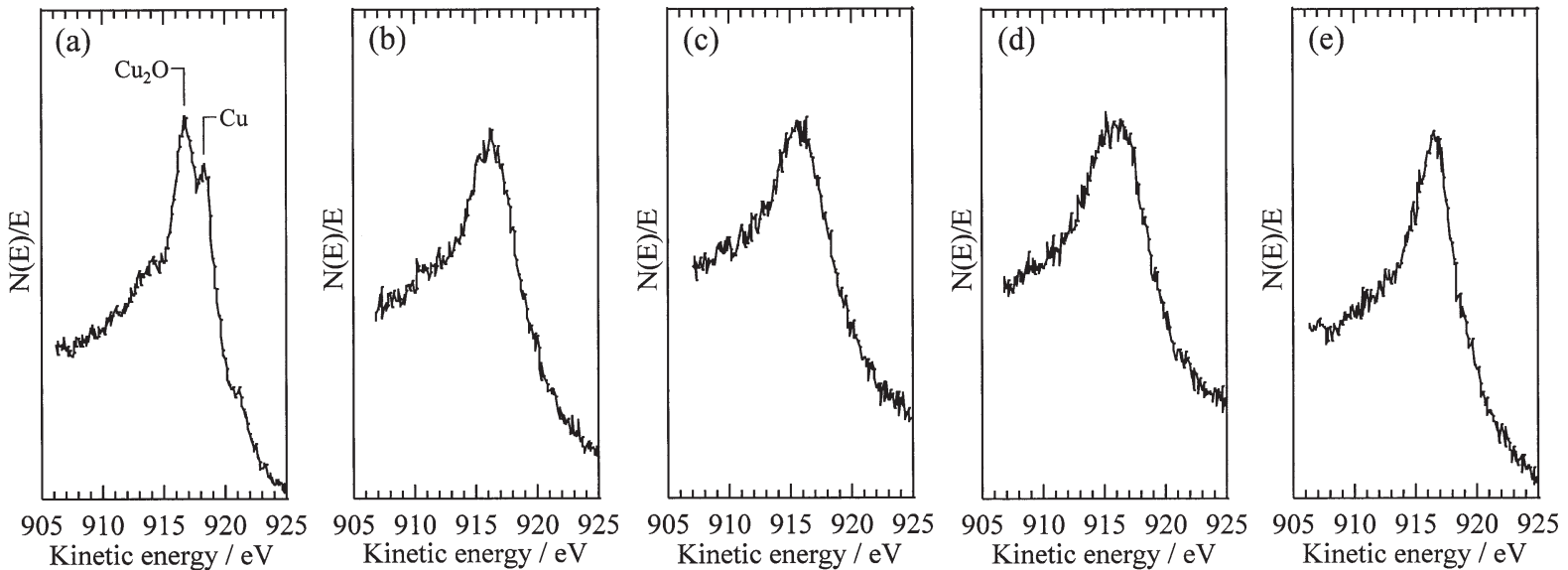

Fig. 5 Detailed XPS scans of Cu LMM Auger region: (a) unexposed, (b) sample A, (c) sample B, (d) sample C, and (e) sample E.
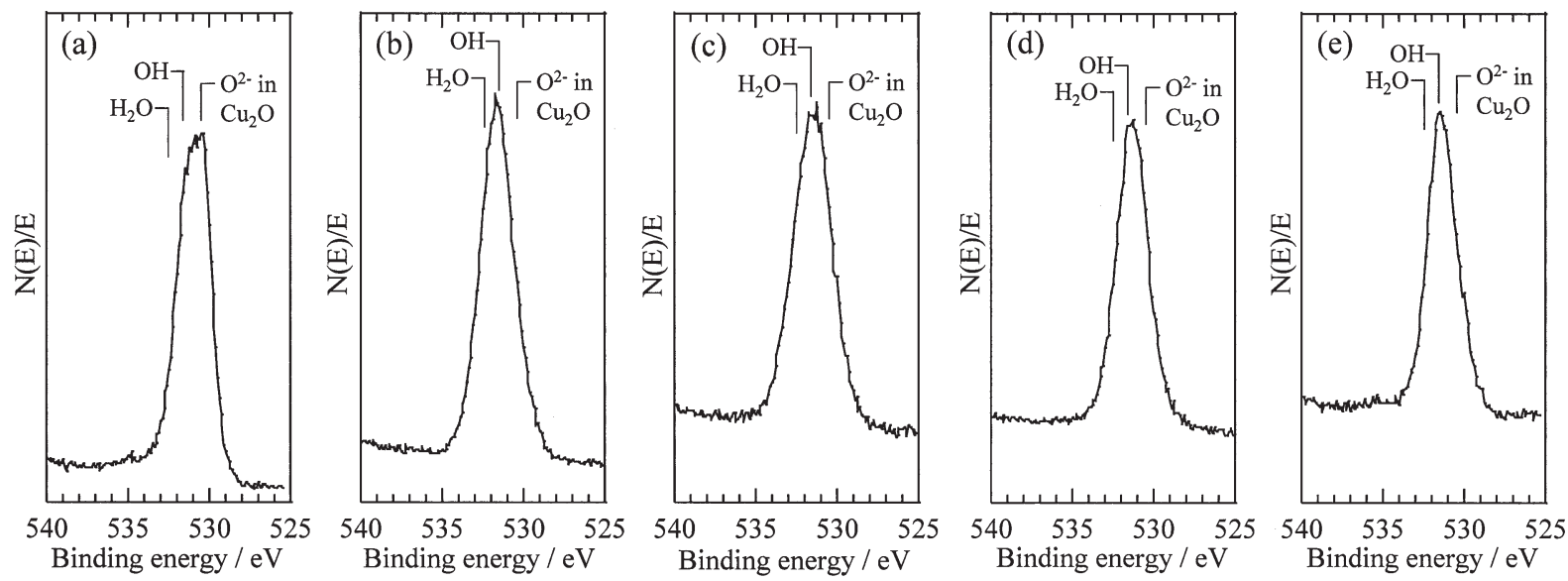

Fig. 6 Detailed XPS scans of O 1s region : (a) unexposed, (b) sample A, (c) sample B, (d) sample C, and (e) sample E.

is one peak at about $916 \mathrm{eV}$, and the spectral shape is broader. The metallic copper component, which can be observed in the spectra for the unexposed copper, was rarely seen because of copper patina formation. The shape of the spectra is very close to those for the $\mathrm{Cu}(\mathrm{OH})_{2}$ and $\mathrm{CuSO}_{4}$ standard samples shown by Chawla et al. ${ }^{21)}$ This indicates that there were cupric species in the copper patinas.

Fig. 6 shows detailed XPS scans of the $O$ 1s region. In the $\mathrm{O}$ 1s spectra of the unexposed copper (Fig. 6(a)), there is a broad peak with its center between 530 and 531 $\mathrm{eV}$. The $\mathrm{O} 1 \mathrm{~s}$ spectra of a copper surface have three components. ${ }^{22-24)}$ The peak at $530.4 \mathrm{eV}$ represents the lattice oxygen $\left(\mathrm{O}^{2-}\right.$ in cuprite $)$, the line defined at $531.4 \mathrm{eV}$ corresponds to oxygen in hydroxyl $(\mathrm{O}-\mathrm{H})$, and the peak at $532.4 \mathrm{eV}$ is the contribution of oxygen in bound water $\left(\mathrm{O}^{-}\right.$ $\mathrm{H}_{2}$ ) or strongly chemisorbed oxygen $\left(\mathrm{O}^{-}\right)$. The $\mathrm{O} 1$ s spectra of the unexposed copper are mainly composed of lattice oxygen and oxygen in hydroxyl. This indicates that cuprite and hydroxide such as $\mathrm{Cu}(\mathrm{OH})_{2}$ were present on the unexposed copper surface. In contrast, in the $\mathrm{O}$ 1s spectra for samples A, B, C, and E, the peak center is shifted about 1 $\mathrm{eV}$ to the higher binding energy side and the peak shape is broader than for the unexposed copper. The oxygen in hydroxyl and oxygen in bound water are the main components in the $\mathrm{O} 1 \mathrm{~s}$ spectra of these samples.

Fig. 7 shows detailed XPS scans of the $S 2 p$ region. The S 2p spectra for samples A, B, and E show that sulfate was the predominant state. This agrees well with the formation of posnjakite. A sulfide component is also seen in the S $2 p$ spectra for sample A, and this indicates that there was reduced sulfur such as $\mathrm{H}_{2} \mathrm{~S}$ and carbonyl sulfide (COS) in the air. For sample $\mathrm{C}$, the $\mathrm{S} 2 \mathrm{p}$ spectra show the coexistence of sulfate and sulfide. Sulfide could be the predominant state of sulfur because the corrosion product that forms on copper in an $\mathrm{H}_{2} \mathrm{~S}$ atmosphere is $\mathrm{Cu}_{2} \mathrm{~S} .{ }^{25)}$ The detection of sulfate is possibly due to the oxidation of sulfide on the copper surface during exposure. Chawla et al. reported the $\mathrm{S} 2 \mathrm{p}$ spectra of $\mathrm{Cu}_{2} \mathrm{~S}$ standard material, and the spectra had both sulfide and sulfate components. ${ }^{21}$ This indicates that a $\mathrm{Cu}_{2} \mathrm{~S}$ surface is easily oxidized in air.

Fig. 8 shows detailed XPS scans of the $\mathrm{N}$ 1s regions. A peak at $398 \mathrm{eV}$ is seen in the $\mathrm{N} 1$ s spectra for the unexposed copper (Fig. 8(a)). This peak is broader and shifted to the higher binding energy side in the $\mathrm{N}$ 1s spectra for samples A, B, C, and E. Forslund et al. reported that this peak can be assigned to ammonium ions $\left(\mathrm{NH}_{4}{ }^{+}\right){ }^{26}$ ) The difference in peak binding energies for the unexposed and 


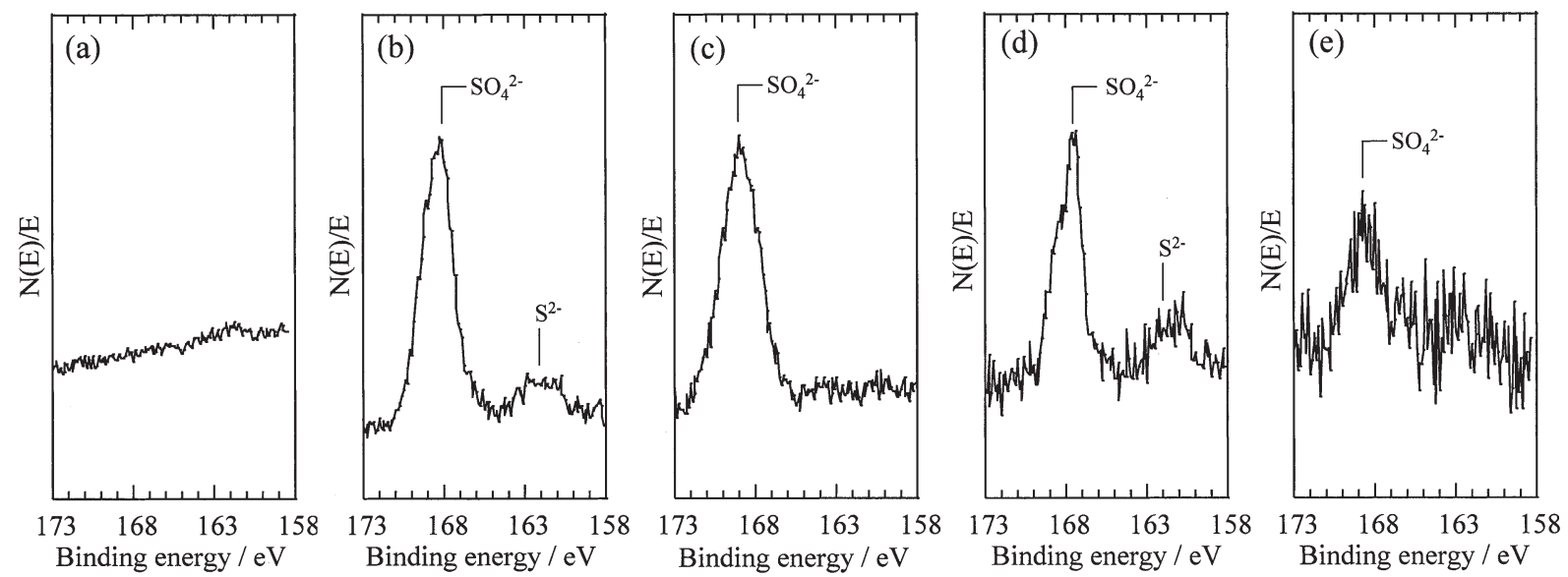

Fig. 7 Detailed XPS scans of S 2p region: (a) unexposed, (b) sample A, (c) sample B, (d) sample C, and (e) sample E.
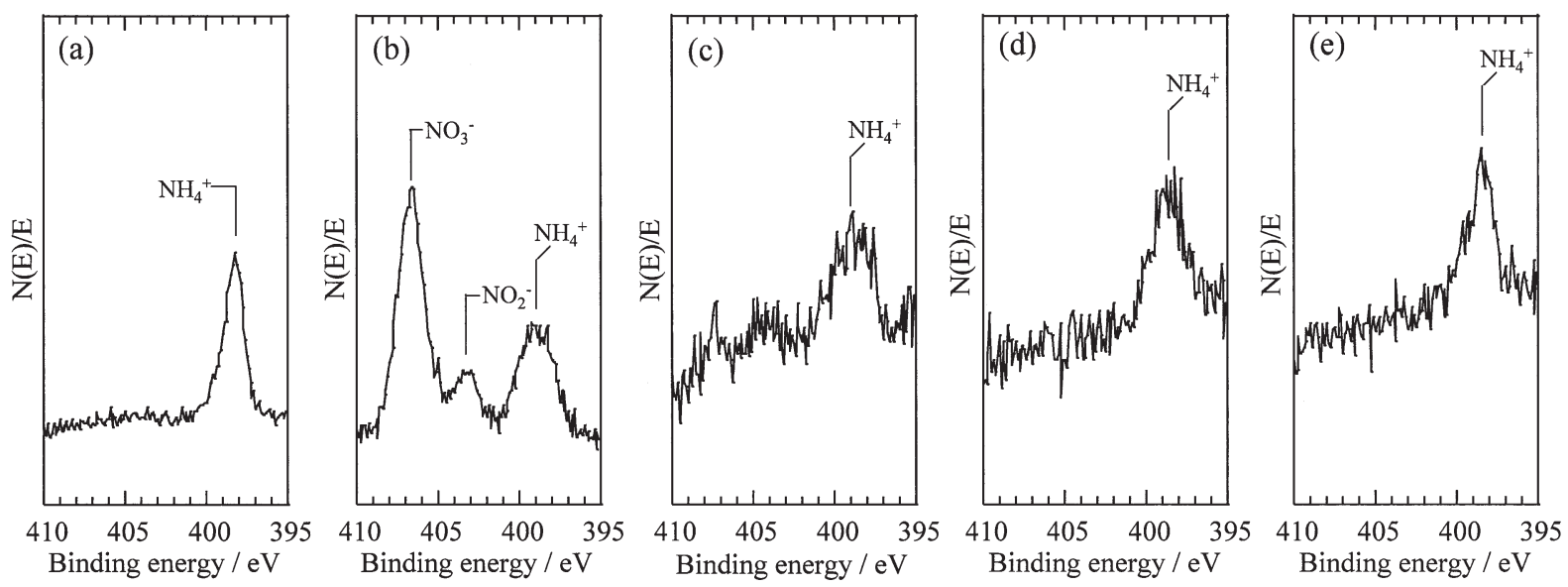

Fig. 8 Detailed XPS scans of N 1s region: (a) unexposed, (b) sample A, (c) sample B, (d) sample C, and (e) sample E.

exposed copper (samples A, B, C, and E) indicates that there was a difference in the chemical states of the ammonium ions. Although the origin is unknown, a possible origin is gaseous ammonia and/or particulate ammonium. Interestingly, we observed two peaks in the $\mathrm{N}$ 1s spectra for sample A besides the peak originating from ammonium ions. As shown in Fig. 8(b), these two peaks can be assigned to nitrite $\left(\mathrm{NO}_{2}^{-}\right)$and nitrate $\left(\mathrm{NO}_{3}^{-}\right)$, respectively. Nitrogen oxide $(\mathrm{NO})$, nitrogen dioxide $\left(\mathrm{NO}_{2}\right)$, and/or nitrite and nitrate ions in the particulate matter are a possible origin of these peaks. Sample A was exposed in an urban area, and the average $\mathrm{NO}$ and $\mathrm{NO}_{2}$ concentrations during exposure were 20 and $35 \mathrm{ppb}$, respectively. ${ }^{11)}$ In contrast, these concentrations in the rural/coastal and hot springs areas were below $10 \mathrm{ppb}{ }^{11)}$ Therefore, the detection of $\mathrm{NO}_{2}{ }^{-}$and $\mathrm{NO}_{3}{ }^{-}$in the $\mathrm{N}$ 1s spectra for sample $\mathrm{A}$ reflects the urban environment.

Fig. 9 shows detailed XPS scans of the $\mathrm{Cl} 2 \mathrm{p}$ regions. In the $\mathrm{Cl} 2 \mathrm{p}$ spectra of the unexposed copper (Fig. 9(a)), no peaks are evident. The $\mathrm{Cl} 2 \mathrm{p}$ spectra for samples $\mathrm{A}, \mathrm{B}, \mathrm{C}$, and $\mathrm{E}$ show one broad peak originating from $\mathrm{Cl} 2 \mathrm{p}_{3 / 2}$ and $2 \mathrm{p}_{1 / 2}$. The peak binding energies were about $198 \mathrm{eV}$, and the peak can be assigned to chloride.

\subsection{Surface observation}

Figs. 10 (a) and (b) show low (500 times) and high (30,000 times) magnification SEM images of sample A. The lower magnification image shows the surface seems as a homogeneous structure, while the higher magnification one reveals that the surface was composed of spherical and plate-like corrosion products. As shown in the XRD patterns for sample A (Fig. 1(a)), cuprite and posnjakite were detected. Jouen et al. showed that "white noodles" form on a uniform layer and assigned them to posnjakite. ${ }^{27)}$ Comizzoli et al. observed similar "noodles" and assigned them to brochantite. ${ }^{28)}$ Lobnig et al. investigated the effect of submicrometer $\left(\mathrm{NH}_{4}\right)_{2} \mathrm{SO}_{4}$ particles on copper corrosion and showed a cross-sectional SEM image of brochantite that had formed on a copper surface. ${ }^{7), 8)}$ The morphology of brochantite has a plate-like structure. Odnevall et al. reported dendritic corrosion products consisting of needles and flakes, and these products correspond to the intermediate phase between cuprite and posnjakite. ${ }^{18)}$ As both posnjakite and brochantite have a monoclinic structure, we believe that the plate-like corrosion products evident in Fig. 10 (b) can be assigned to posnjakite. In contrast, the spherical corrosion products correspond to cuprite, as demonstrated by Aastrup et al. using tapping 

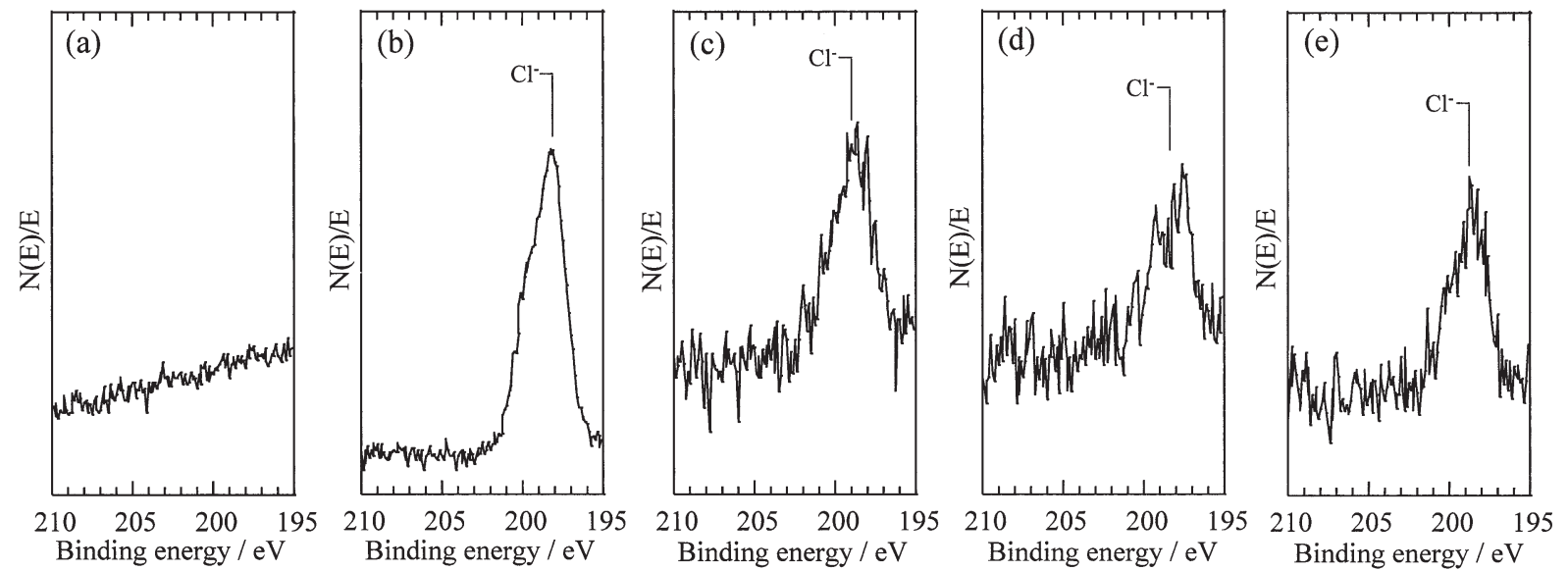

Fig. 9 Detailed XPS scans of $\mathrm{Cl} 2$ p region : (a) unexposed, (b) sample A, (c) sample B, (d) sample C, and (e) sample E.

mode atomic force microscopy and infrared reflection adsorption spectroscopy. ${ }^{29)}$ As shown in Fig 10(b), posnjakite formed on cuprite. A posnjakite formation mechanism was proposed by Lobnig et al. ${ }^{8)}$ and Odnevall et al. ${ }^{18)}$ Odnevall et al. showed that posnjakite forms on cuprite and that the existence of intermediate non-crystalline compounds composed of copper and sulfate are present before posnjakite formation. ${ }^{18)}$

Fig. 10 (c) shows a low magnification (500 times) SEM image of sample B. Three different contrast areas were observed (A, B, and C), indicating that the corroded surface had a heterogeneous structure. Figures 10 (d), (e), and (f) show high magnification (30,000 times) images of the bright (A), gray (B), and dark (C) areas, respectively. In the bright area, plate-like and spherical corrosion products were observed, while there were many swellings in the gray area. In the dark area, the surface was covered with ultra small spherical corrosion products estimated to be several tens of nanometers in size. As for sample A, the spherical corrosion products in all areas can be assigned to cuprite. The plate-like corrosion products found in the bright area (Fig. 10 (d)) are attributed to posnjakite.

Fig. 11(a) shows a low magnification (500 times) SEM image of sample C. Two distinctly different areas were clearly observed : bright (D) and dark (E). Figures 11(b) and (c), respectively, show high magnification $(30,000$ times) images of these areas. In the bright area, we observed small spherical corrosion products less than 0.1 $\mu \mathrm{m}$ in size. Spherical corrosion products were also found in the dark area, but their size and morphology were quite different. The size ranged between 0.1 and $0.2 \mu \mathrm{m}$, and they formed mounds. Another feature of the dark area was the existence of cracks, which indicates the formation of a thicker corrosion product layer. Graedel et al. analyzed the surface morphology of copper exposed in a $3.5 \mathrm{ppm} \mathrm{H}_{2} \mathrm{~S}$ environment ${ }^{30)}$ and found that small bright mounds of copper sulfide. These mounds grew and spread with the exposure time. The SEM image of the dark area agrees well with the images taken by Graedel et al. However, we cannot attribute the spherical corrosion products observed in
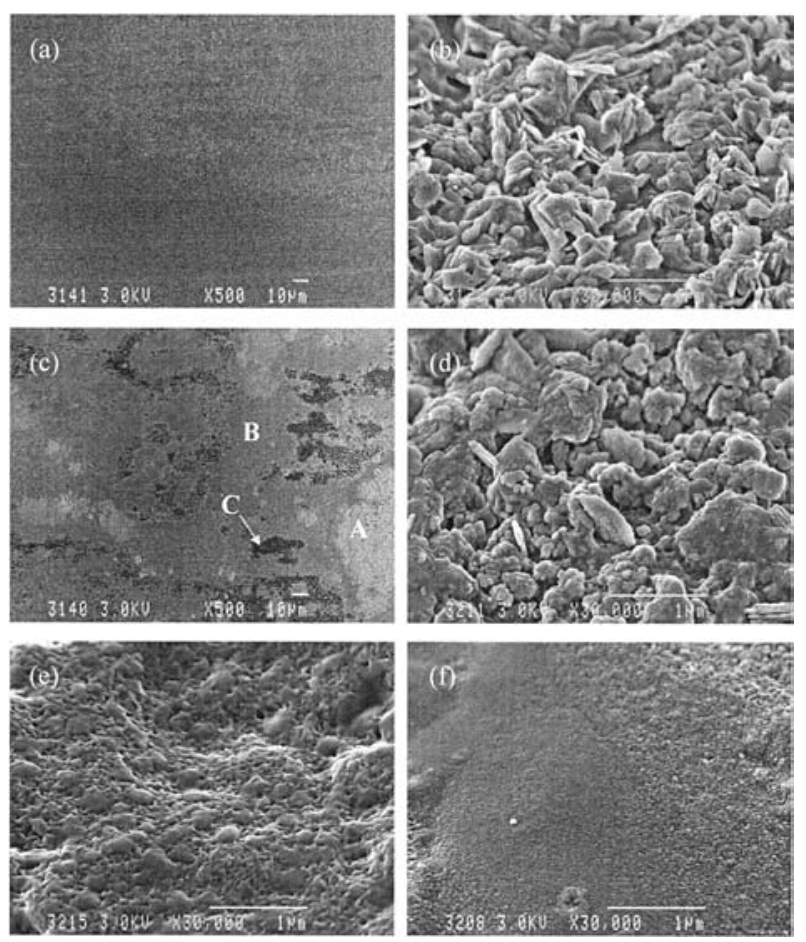

Fig. 10 SEM images of samples A and B : (a) low magnification image (500 times) of sample A, (b) high magnification image (30,000 times) of typical area in sample A, (c) low magnification image (500 times) of sample B, (d) high magnification image (30,000 times) of area A in sample B, (e) high magnification image (30,000 times) of area B in sample B, and (f) high magnification image $(30,000$ times) of area $\mathrm{C}$ in sample $\mathrm{B}$.

the dark area to only copper sulfide because our exposure conditions had a much lower $\mathrm{H}_{2} \mathrm{~S}$ concentration (average $\mathrm{H}_{2} \mathrm{~S}$ concentration of $13 \mathrm{ppb}$ ). As described previously, both cuprite and copper sulfide $\left(\mathrm{Cu}_{2} \mathrm{~S}\right)$ were found on sample $\mathrm{C}$. Therefore, the spherical corrosion products can be attributed to both cuprite and $\mathrm{Cu}_{2} \mathrm{~S}$.

Figs. 11(d) and (e) show low (500 times) and high (10,000 times) magnification SEM images of sample D. The horizontal scratches evident in Fig. 11(d) were formed during the cold rolling process used to manufacture the copper plate. At lower magnification, the corroded 

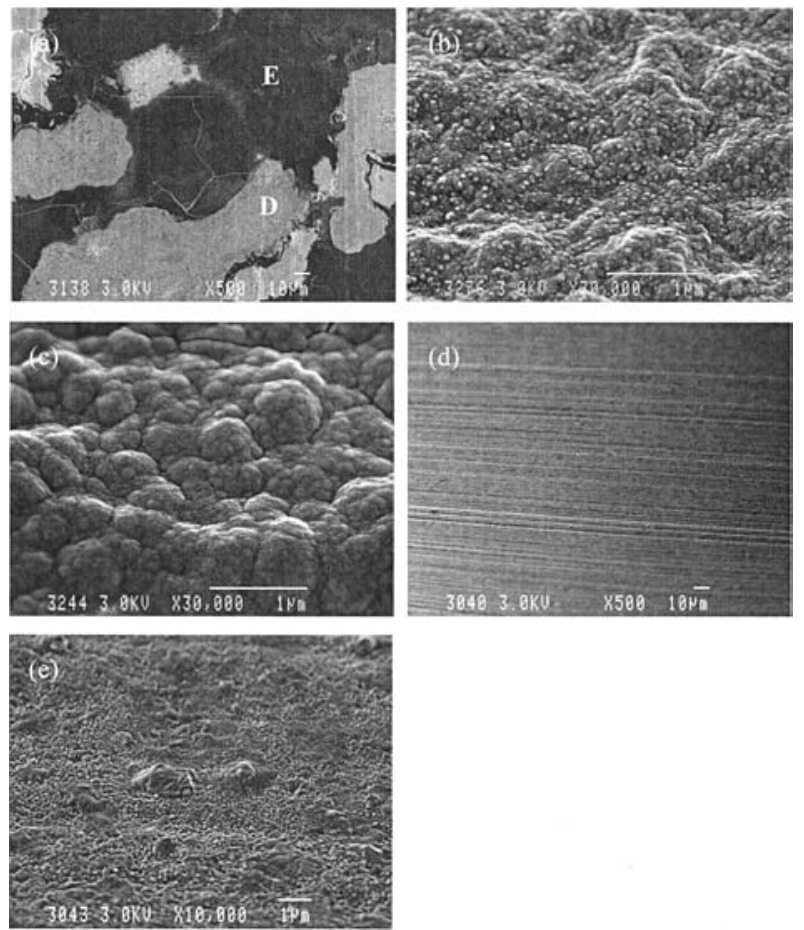

Fig. 11 SEM images of samples C and D : (a) low magnification image (500 times) of sample C, (b) high magnification image (30,000 times) of area D in sample C, (c) high magnification image (30,000 times) of area $\mathrm{E}$ in sample C, (d) low magnification image (500 times) of sample D, and (e) high magnification image (10,000 times) of typical area in sample D. The cracks evident in (a) were generated by sulfide corrosion products.

surface appears homogeneous. At higher magnification, there are swellings, a few micrometers in diameter. There is a difference in surface morphologies between the higher magnification image of sample D and that of sample A (Fig. 10 (b) ) although cuprite and posnjakite were detected in the XRD patterns for both samples. The small spherical corrosion products evident in Fig. 11(e) can be assigned to cuprite, whereas the swellings can be assigned to posnjakite. As previously reported, these swellings change to plate-like corrosion products as the exposure time lengthens. ${ }^{17)}$

Fig. 12 shows low (500 times) and high (10,000 times) magnification SEM images of sample E. As seen in the lower magnification images of samples $\mathrm{A}$ and $\mathrm{D}$, the corroded surface appears to have had a homogeneous structure in the low magnification image (Fig. $12(\mathrm{a})$ ). At higher magnification (Fig. 12(b)), many swellings composed of spherical corrosion products are evident. This image is similar to that of sample D (Fig. 11(e)). The similar surface morphologies observed in samples B (gray area), D, and $\mathrm{E}$ exhibit the corrosion product formation process before the corrosion product is fully developed.

\subsection{Depth profiling analysis by GDOES}

The oxygen, copper, and carbon elemental depth profiles for sample A are shown in Fig. 13 (a). The oxygen depth profile abruptly increased from the uppermost sur-
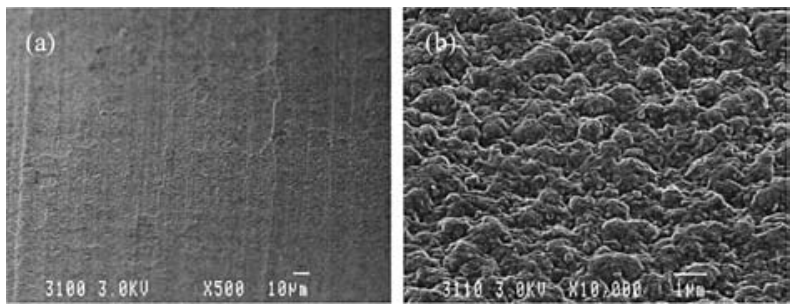

Fig. 12 SEM images of sample E : (a) low magnification image (500 times) and (b) high magnification image $(10,000$ times).

face, and its intensity was almost constant at $0.12 \mu \mathrm{m}$. Its intensity then decreased and reached a background value at about $0.3 \mu \mathrm{m}$. As described above, cuprite and posnjakite formed on sample A. Therefore, the oxygen depth profile originated from these two phases. In contrast, the copper depth profile exhibited an inverse profile. Its intensity increased monotonically until $0.3 \mu \mathrm{m}$ and reached a steady state value. The carbon intensity was high at the uppermost surface due to surface contamination. It abruptly decreased until $0.02 \mu \mathrm{m}$ and then slowly decreased.

The sulfur, chlorine, and nitrogen depth profiles for sample A are shown in Fig. 13(b). The sulfur depth profile exhibited a maximum at $0.01 \mu \mathrm{m}$ and a constant value between 0.04 and $0.1 \mu \mathrm{m}$. Then the sulfur intensity decreased and reached a background value. Although the origin of the peak at $0.01 \mu \mathrm{m}$ is not clear, the sulfur depth profile originated from posnjakite. The sulfur intensity decreased faster than that of the oxygen. This indicates that sulfur was present in the upper part of the patinas. As reported by Franey et al., the copper patinas that form on copper during lengthy exposure have a bilayer structure; that is, the patinas are composed of a basic copper sulfate such as brochantite on cuprite. ${ }^{31)}$ Our results clearly show that a bilayer structure forms on copper exposed even for only a month. In contrast, the chlorine intensity decreased from the uppermost surface and peaked at $0.14 \mu \mathrm{m}$. That is, the chlorine penetrated the patina. As shown in the $\mathrm{Cl}$ 2p XPS spectra (Fig. 9(b)), chlorine existed as chloride ions. The chloride ions dissolve the cuprite and penetrate the copper patina in accordance with ${ }^{32)}$

$$
\frac{1}{2} \mathrm{Cu}_{2} \mathrm{O}+2 \mathrm{Cl}^{-}+\mathrm{H}^{+} \rightarrow \mathrm{CuCl}_{2}{ }^{-}+\frac{1}{2} \mathrm{H}_{2} \mathrm{O}
$$

Alternatively, the formation of rough surfaces due to the posnjakite formation causes the apparent penetration of chlorine into the patina. As shown by the XRD patterns, chlorine-containing corrosion products such as atacamite and nantokite were not observed. Nantokite $(\mathrm{CuCl})$ was observed in the XRD patterns of copper exposed for one year in a suburban area. ${ }^{17)}$ Therefore, chloride ions form copper chloride complex and/or nantokite. This is the first report of a difference in the depth profiles of sulfur and chlorine for copper exposed for one month. This indicates that these two elements play different roles in the atmospheric copper corrosion. The nitrogen depth profile was similar to the sulfur one. 

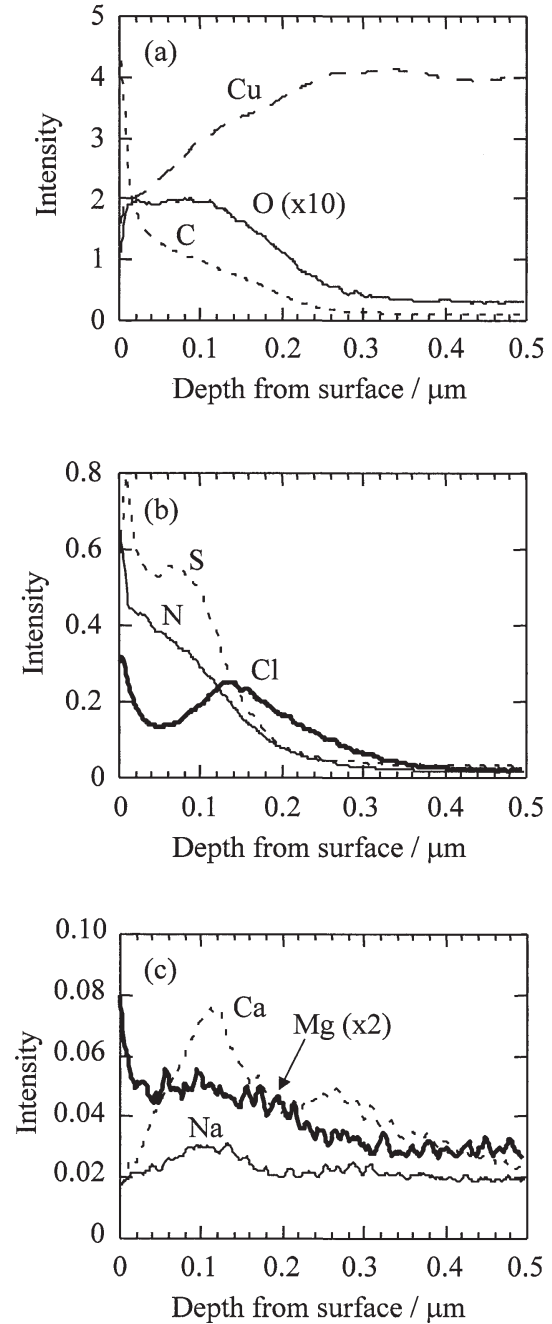

Fig. 13 GDOES depth profiles for sample A: (a) copper, oxygen, and carbon, (b) sulfur, chlorine, and nitrogen, and (c) sodium, calcium, and magnesium.

The sodium, calcium, and magnesium depth profiles are shown in Fig. 13 (c). These three elements possibly originated from sea-salt aerosol. They could not be detected by Auger electron spectroscopy (AES) ${ }^{33)}$ This indicates that GDOES has higher sensitivity. Their depth profiles showed a maximum at about $0.1 \mu \mathrm{m}$, which does not agree with the chlorine peak. This indicates that the deposited chlorides such as $\mathrm{NaCl}$ dissolved in the surface electrolyte. The calcium profile had another maximum at around 0.25 $\mu \mathrm{m}$.

Fig. 14 shows the elemental depth profiles for sample B. The oxygen depth profile (Fig.14(a)) was broader than that for sample A, indicating thicker patina formation. The exposure site for sample B was a rural/coastal area, so seasalt deposition was a factor. This possibly promoted corrosion of the copper. The high average relative humidity during exposure (87\%) was also possibly a factor in corrosion promotion. The copper depth profile increased until 0.1 $\mu \mathrm{m}$, then decreased and increased again at $0.3 \mu \mathrm{m}$. The increase after $0.3 \mu \mathrm{m}$ corresponds to the decrease in the oxygen intensity. The behavior in the area between the
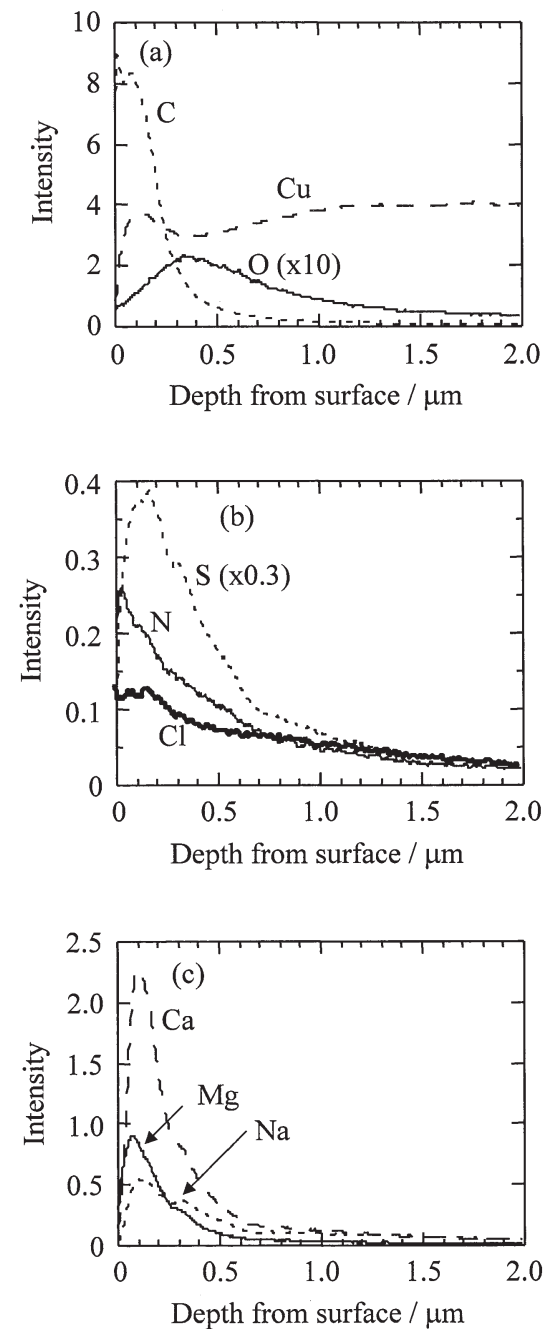

Fig. 14 GDOES depth profiles for sample B : (a) copper, oxygen, and carbon, (b) sulfur, chlorine, and nitrogen, and (c) sodium, calcium, and magnesium.

uppermost surface and a depth of $0.3 \mu \mathrm{m}$ was affected by the existence of posnjakite at the surface. The carbon depth profile decreased abruptly below $0.1 \mu \mathrm{m}$, and the carbon layer was thicker than that of sample A.

The XRD pattern for sample B showed that cuprite and posnjakite formed on the surface. As shown in Fig. 14 (b), the sulfur depth profile had a maximum at about $0.15 \mu \mathrm{m}$ and then decreased. The sulfur originated from posnjakite, as with sample A. However, the sulfur intensity was stronger and the sulfur layer was thicker than those of sample A. The sulfur intensity also decreased faster than that of the oxygen, as evidenced by the sulfur depth profile for sample A. This indicates that a bilayer structure also formed on sample B. The chlorine depth profile revealed a maximum at $0.2 \mu \mathrm{m}$, but it was not in a deeper region. As shown in the SEM image (Fig. 10(c)), there were three different types of areas on sample B. The chlorine depth profiles of the bright and gray areas by AES showed a maximum in a deeper region. ${ }^{13)}$ The GDOES depth profile reflects average data for a diameter of $4 \mathrm{~mm}$ diameter, so the chlorine depth profile had a broader shape, indicating 

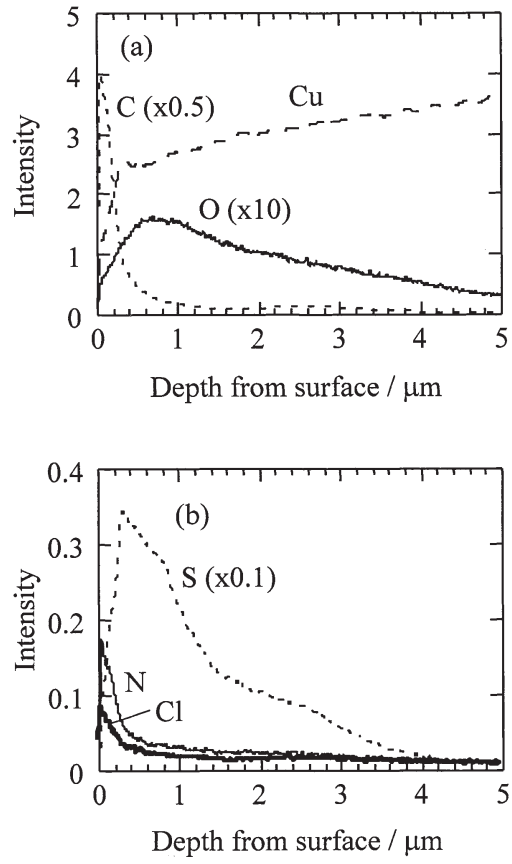

Fig. 15 GDOES depth profiles for sample C : (a) copper, oxygen, and carbon, and (b) sulfur, chlorine, and nitrogen.

the chlorine penetrated the patina. The nitrogen depth profile was similar to that for sample A ; however, the nitrogen intensity rapidly decreased.

Fig. 14 (c) shows the depth profiles of sodium, calcium, and magnesium for sample $B$. Compared to those for sample $A$, the intensities of these elements were much stronger. This indicates that a large amount of sea-salt aerosols accumulated on sample B. The depth profiles had a maximum at about $0.1 \mu \mathrm{m}$ and then decreased. There were a maximum or shoulder at $0.3 \mu \mathrm{m}$, indicating a bimodal distribution. The maximum position at about 0.1 $\mu \mathrm{m}$ agreed with the chlorine maximum position. This possibly reflected the presence of chloride, which does not dissolve in surface electrolyte.

Fig. 15 shows the elemental depth profiles for sample C. The oxygen depth profile (Fig. 15(a)) reached a maximum at between 0.6 and $1.0 \mu \mathrm{m}$ and then slowly decreased. However, it did not reach a background value even at $5 \mu \mathrm{m}$. Therefore, the oxygen layer of sample $\mathrm{C}$ was thicker than those of samples A and B. This agrees qualitatively with the cuprite intensity observed in the XRD patterns. The copper depth profile increased rapidly until $0.3 \mu \mathrm{m}$ and then slowly increased. The carbon depth profile showed a maximum at about $0.1 \mu \mathrm{m}$ and then abruptly decreased.

In the XRD pattern for sample $\mathrm{C}$, only cuprite was detected as a crystalline corrosion product although the amount of sulfur was the largest (Table 2). As shown in Fig. 15(b), the sulfur intensity was very strong, indicating the presence of a large amount of sulfur in the patina. The sulfur depth profile revealed a maximum at $0.3 \mu \mathrm{m}$ and then decreased. The sulfur existed mainly in the upper part of the patina. The oxygen and sulfur depth profiles
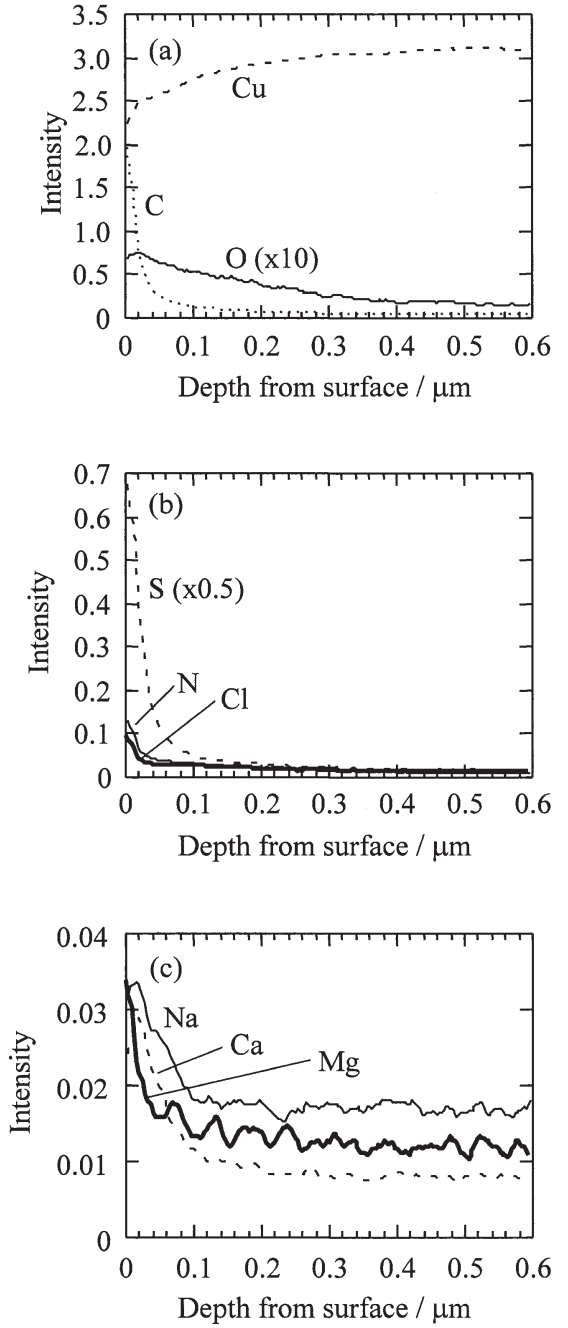

Fig. 16 GDOES depth profiles for sample D : (a) copper, oxygen, and carbon, (b) sulfur, chlorine, and nitrogen, and (c) sodium, calcium, and magnesium.

indicate that cuprite formed first and then sulfidation reaction started. In contrast, the chlorine intensity was strong at the uppermost surface and then decreased. It reached a background value at about $0.5 \mu \mathrm{m}$. The exposure site for sample $\mathrm{C}$ was $100 \mathrm{~km}$ from the seashore, so the effect of sea-salt aerosol was negligible. Therefore, the small intensity of chlorine and the absence of sodium, calcium, and magnesium are reasonable. The nitrogen depth profile was similar to the chlorine one. The nitrogen intensity was high at the uppermost surface and then decreased rapidly.

Fig. 16 shows the elemental depth profiles for sample D. The oxygen depth profile showed a maximum at $0.02 \mu \mathrm{m}$ and then decreased slowly (Fig. 16(a)). The oxygen layer width was estimated to be $0.4 \mu \mathrm{m}$. Compared to the oxygen depth profile for sample A, the oxygen intensity was weaker. Although cuprite and posnjakite were found on both samples, the two phases were not fully developed in sample $\mathrm{D}$. The copper depth profile increased until 0.4 $\mu \mathrm{m}$ and reached a steady state value. In contrast, the carbon depth profile decreased rapidly from the uppermost surface. 

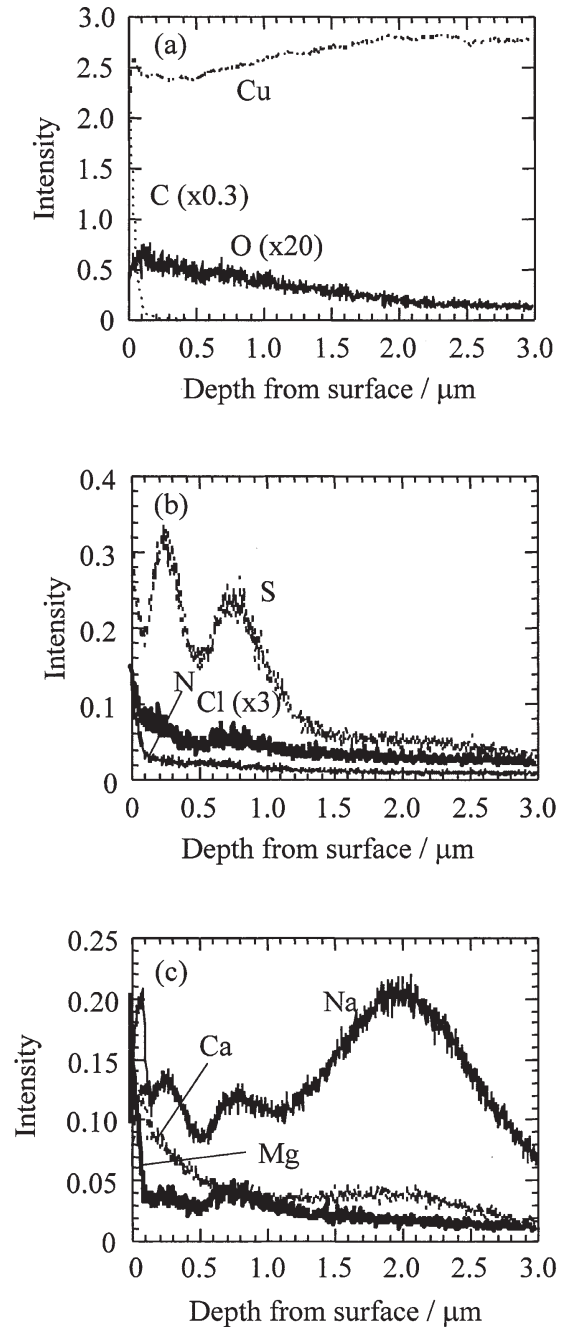

Fig. 17 GDOES depth profiles for sample E : (a) copper, oxygen, and carbon, (b) sulfur, chlorine, and nitrogen, and (c) sodium, calcium, and magnesium.

As shown in Fig. 16(b), the sulfur intensity decreased rapidly from the uppermost surface. The sulfur layer was much shallower than that of sample A, which agrees well with the XRF results (Table 2). Comparison of the oxygen depth profile with the sulfur one shows that a bilayer structure also formed on sample D. The nitrogen and chlorine depth profiles were similar. Their intensities were high at the uppermost surface and decreased rapidly.

Fig. 16(c) shows the depth profiles of sodium, calcium, and magnesium. The depth profiles of these elements were also similar and did not show a maximum. The intensities of these elements were smaller than those observed for sample A (Fig. 13 (c)). This indicates that the effect of seasalt aerosol was negligible.

The elemental depth profiles for sample E are shown in Fig. 17. The oxygen depth profile reached a peak at $0.1 \mu \mathrm{m}$ and then decreased slowly. The oxygen intensity reached a background value at about $2.5 \mu \mathrm{m}$. The copper depth profile showed a profile inverse to that for oxygen. The carbon intensity rapidly decreased from the uppermost surface and reached a background value within $0.3 \mu \mathrm{m}$.
As shown in Fig. 17 (b), the sulfur depth profile had two peaks. As shown in the XRD pattern for sample E (Fig. $1(\mathrm{e})$ ), only posnjakite was found as a sulfur-containing phase. Therefore, it is reasonable to assume that the sulfur depth profile originated from posnjakite. A possible explanation of the distribution shown in Fig. 17 (b) is the rough structure revealed in the SEM image (Fig. 12(b)). Compared to the oxygen depth profile, there was sulfur in the upper part of the patina, meaning that a bilayer structure also formed on sample E. The chlorine depth profile showed a maximum at around $0.7 \mu \mathrm{m}$; however, the chlorine did not penetrate the patina as shown in the elemental depth profiles for sample A. The nitrogen depth profile decreased rapidly from the uppermost surface.

As shown in Fig. 17 (c), the depth profiles of sodium, calcium, and magnesium differed in terms of shape. This was not seen for samples A, B, and D. As the exposure site for sample E was only about $300 \mathrm{~m}$ from the seashore, sea-salt aerosol is a possible origin of these elements. The reason for the shapes of the depth profiles is not clear at present.

\subsection{Role of sulfur in early stage of copper patina- tion}

Two kinds of sulfur species have to be considered when we discuss the role of sulfur in the early stage of copper patination. One is oxidized sulfur, such as $\mathrm{SO}_{2}$ and $\mathrm{SO}_{4}{ }^{2-}$, the other is reduced sulfur, such as $\mathrm{H}_{2} \mathrm{~S}$ and COS. The former is commonly found in most areas while the latter is found mainly in areas near hot springs and similar environments. In volcanic areas, both $\mathrm{SO}_{2}$ and $\mathrm{H}_{2} \mathrm{~S}$ play a role in atmospheric copper corrosion. ${ }^{15), 16)}$

When $\mathrm{SO}_{2}$ absorbs on surface electrolyte, the dissolution can be described by

$$
\mathrm{SO}_{2}+\mathrm{H}_{2} \mathrm{O} \rightarrow \mathrm{H}^{+}+\mathrm{HSO}_{3}{ }^{-}
$$

If the $\mathrm{pH}$ of the surface electrolyte is high, the bisulfite ions $\left(\mathrm{HSO}_{3}{ }^{-}\right)$further dissolve into protons and sulfite ions.

$$
\mathrm{HSO}_{3}{ }^{-} \rightarrow \mathrm{H}^{+}+\mathrm{SO}_{3}{ }^{2-}
$$

The sulfite ions are oxidized by the dissolved oxygen in the surface electrolyte, and this results in the formation of sulfate ions. ${ }^{34}$

$$
2 \mathrm{SO}_{3}{ }^{2-}+\mathrm{O}_{2} \rightarrow 2 \mathrm{SO}_{4}{ }^{2-}
$$

The oxidation of sulfite ions is readily converted into sulfate ions by ozone $\left(\mathrm{O}_{3}\right)$, hydrogen peroxide $\left(\mathrm{H}_{2} \mathrm{O}_{2}\right)$, and transition metal ions, all of which are commonly found in the surface electrolyte on copper ${ }^{35)}$ The first two originate from gaseous compounds, and the ions originate from particulate matter (PM) in the atmosphere.

Sulfate ions also originate from the sulfate salts in PM. A typical example is ammonium sulfate $\left(\left(\mathrm{NH}_{4}\right)_{2} \mathrm{SO}_{4}\right)$ having hygroscopic characteristics. Airborne sulfate, nitrate, and chloride salts play a role in the corrosion of electronic devices and components indoors. ${ }^{36)}$ Of these salts, sulfate ions are the most abundant and exist as $\left(\mathrm{NH}_{4}\right)_{2} \mathrm{SO}_{4}{ }^{36)} \mathrm{We}$ measured the concentrations of water soluble ions in the suspended PM collected outside our telephone switching 
center in the rural area and found that the highest concentration of ions was that of sulfate ions. ${ }^{37)}$ This indicates that the deposition of sulfate ions has to be considered when investigating outdoor copper corrosion. When $\left(\mathrm{NH}_{4}\right)_{2} \mathrm{SO}_{4}$ is deposited on the surface electrolyte on copper, it dissolves into $\mathrm{NH}_{4}{ }^{+}$and $\mathrm{SO}_{4}{ }^{2-}$.

$$
\left(\mathrm{NH}_{4}\right)_{2} \mathrm{SO}_{4} \rightarrow 2 \mathrm{NH}_{4}{ }^{+}+\mathrm{SO}_{4}{ }^{2-}
$$

Above the critical relative humidity $(\mathrm{CRH})$, which is $81 \%$ at $300 \mathrm{~K},{ }^{8)}\left(\mathrm{NH}_{4}\right)_{2} \mathrm{SO}_{4}$ deliquesces, as represented by equation (5). As shown in Table 1, the RH is likely to exceed the $\mathrm{CRH}$ during exposure.

At the interface between copper and the surface electrolyte, two anodic reactions occur :

$$
\begin{aligned}
& \mathrm{Cu} \rightarrow \mathrm{Cu}^{+}+\mathrm{e}^{-} \\
& \mathrm{Cu}^{+} \rightarrow \mathrm{Cu}^{2+}+\mathrm{e}^{-}
\end{aligned}
$$

As shown in Fig. 5(a), cuprite was present on the surface of the unexposed copper. Therefore, the anodic reaction represented by

$$
\mathrm{Cu}_{2} \mathrm{O}+2 \mathrm{H}^{+} \rightarrow 2 \mathrm{Cu}^{2+}+\mathrm{H}_{2} \mathrm{O}+2 \mathrm{e}^{-}
$$

possibly dominates. This dissolution is accelerated by the dissolution of $\mathrm{SO}_{2}$ into the surface electrolyte. ${ }^{6)}$ The dissolution of $\left(\mathrm{NH}_{4}\right)_{2} \mathrm{SO}_{4}$, also lowers the $\mathrm{pH}$ of the surface electrolyte because the measured $\mathrm{pH}$ of the saturated $\left(\mathrm{NH}_{4}\right)_{2} \mathrm{SO}_{4}$ solution was 5.6. ${ }^{38)}$ In a $\left(\mathrm{NH}_{4}\right)_{2} \mathrm{SO}_{4}$ solution, copper dissolves, forming a copper-ammonia complex. ${ }^{8)}$

$$
\begin{aligned}
& \mathrm{NH}_{4}^{+} \rightarrow \mathrm{NH}_{3}+\mathrm{H}^{+} \\
& \mathrm{Cu}+2 \mathrm{NH}_{3} \rightarrow \mathrm{Cu}\left(\mathrm{NH}_{3}\right)_{2}{ }^{+}+\mathrm{e}^{-}
\end{aligned}
$$

The monovalent ions, $\mathrm{Cu}\left(\mathrm{NH}_{3}\right)_{2}{ }^{+}$, are further oxidized by the dissolved oxygen. ${ }^{8}$

$$
4 \mathrm{Cu}\left(\mathrm{NH}_{3}\right)_{2}{ }^{+}+\mathrm{O}_{2}+4 \mathrm{H}^{+} \rightarrow 4 \mathrm{Cu}\left(\mathrm{NH}_{3}\right)_{2}{ }^{2+}+2 \mathrm{H}_{2} \mathrm{O}
$$

As reported by Lobnig et al., the $\mathrm{NH}_{3}$ in surface electrolyte gradually evaporates. ${ }^{8)}$ Therefore, the $\mathrm{Cu}\left(\mathrm{NH}_{3}\right)_{2}{ }^{2+}$ ions decompose before formation of basic copper sulfates.

$$
\mathrm{Cu}\left(\mathrm{NH}_{3}\right)_{2}{ }^{2+} \rightarrow \mathrm{Cu}^{2+}+2 \mathrm{NH}_{3}
$$

In contrast, the cathodic reaction is oxygen reduction.

$$
\mathrm{O}_{2}+2 \mathrm{H}_{2} \mathrm{O}+4 \mathrm{e}^{-} \rightarrow 4 \mathrm{OH}^{-}
$$

Cuprite is a primary corrosion product on copper. ${ }^{9), 10)}$ Two possible reactions are considered. One is a chemical reaction between copper and oxygen in the air.

$$
4 \mathrm{Cu}+\mathrm{O}_{2} \rightarrow 2 \mathrm{Cu}_{2} \mathrm{O}
$$

Cuprite film formed by the process represented by equation (14) is called "air-formed film." The other possible reaction is an electrochemical reaction originating from the processed represented by equations (6) and (13).

$$
2 \mathrm{Cu}^{+}+2 \mathrm{OH}^{-} \rightarrow \mathrm{Cu}_{2} \mathrm{O}+\mathrm{H}_{2} \mathrm{O}
$$

Cuprite is also formed by the process represented by the following equation in the presence of $\mathrm{Cu}\left(\mathrm{NH}_{3}\right)_{2}{ }^{+}$ions. ${ }^{8)}$

$$
2 \mathrm{Cu}\left(\mathrm{NH}_{3}\right)_{2}{ }^{+}+\mathrm{H}_{2} \mathrm{O} \rightarrow \mathrm{Cu}_{2} \mathrm{O}+2 \mathrm{H}^{+}+4 \mathrm{NH}_{3}
$$

As shown in Table 1 , the average relative humidity during exposure was beyond 65\%. Therefore, an electrochemical reaction is more likely to occur rather than a chemical one. As discussed in 3.4, cuprite existed as a spherical crystal.

As shown in Fig. 1, the XRD patterns of the copper exposed in four different areas revealed the existence of hydrated basic copper sulfate, posnjakite. When the cupric, sulfate, and hydroxyl ion concentrations are high enough to form posnjakite, this phase starts to precipitate on the cuprite surface. $^{8)}$

$$
\begin{aligned}
4 \mathrm{Cu}^{2+}+ & \mathrm{SO}_{4}{ }^{2-}+6 \mathrm{OH}^{-}+\mathrm{H}_{2} \mathrm{O} \\
& \rightarrow \mathrm{Cu}_{4} \mathrm{SO}_{4}(\mathrm{OH})_{6} \cdot \mathrm{H}_{2} \mathrm{O}
\end{aligned}
$$

As described above, there are two roles of oxidized sulfur species, including $\mathrm{SO}_{2}$ and $\left(\mathrm{NH}_{4}\right)_{2} \mathrm{SO}_{4}$, in the early stage of copper patination. One is lowering the $\mathrm{pH}$ of the surface electrolyte, which accelerates the dissolution of the initially formed cuprite. The other is the formation of posnjakite by the process represented by equation (17). The posnjakite existed as plate-like corrosion products (Figs. 10 (b) and (d)) or swellings (Figs. 10 (e), 11 (e), and 12 (b)). Both morphological features correspond to a rough surface, meaning more sites at which electrochemical reactions can occur. The swellings observed in Fig. 12 (b) changed to plate-like corrosion products due to the dissolution-reprecipitation reaction in the surface electrolyte, as shown previously. ${ }^{17)}$ As the exposure time lengthens, posnjakite changes to brochantite.9), 17),18

For reduced sulfur species such as $\mathrm{H}_{2} \mathrm{~S}$ and COS, the dissolution in the electrolyte can be expressed as

$$
\begin{aligned}
& \mathrm{H}_{2} \mathrm{~S} \rightarrow \mathrm{H}^{+}+\mathrm{HS}^{-} \\
& \mathrm{HS}^{-} \rightarrow \mathrm{H}^{+}+\mathrm{S}^{2-}
\end{aligned}
$$

It is worth noting that $\mathrm{COS}$ changes to $\mathrm{H}_{2} \mathrm{~S}$ when it dissolves in water. ${ }^{39)}$

$$
\mathrm{COS}+\mathrm{H}_{2} \mathrm{O} \rightarrow \mathrm{H}_{2} \mathrm{~S}+\mathrm{CO}_{2}
$$

As shown by equations (18) and (19), the $\mathrm{pH}$ of the surface electrolyte becomes weakly acidic. The cathodic reaction described by equation (13) occurs concurrently, so charge neutrality is maintained. This results in the formation of cuprite by the process represented by equation (15).

The corrosion products on the copper exposed in the hot springs area were composed of cuprite and $\mathrm{Cu}_{2} \mathrm{~S}$. The latter was non-crystalline phase, as shown by transmission electron microscopy and electron diffraction analysis. ${ }^{12)}$ As shown in Fig. 15 (b), the sulfur was in the upper part of the patina. The distribution shown in the figure indicates that cuprite formation, that is, oxidation of the copper, occurred first, and then sulfidation started. Because $\mathrm{HS}^{-}$ions are predominant when the $\mathrm{pH}$ of surface electrolyte is neutral, the sulfidation reaction can be expressed as

$$
2 \mathrm{Cu}^{+}+\mathrm{HS}^{-}+\mathrm{OH}^{-} \rightarrow \mathrm{Cu}_{2} \mathrm{~S}+\mathrm{H}_{2} \mathrm{O}
$$

As shown in the S 2p XPS spectra for sample C (Fig. $7(\mathrm{~d})$ ), the surface of the $\mathrm{Cu}_{2} \mathrm{~S}$, which is unstable in air, ${ }^{21}$ oxidized, forming sulfate. A typical feature of sulfide corrosion products is crack generation, as shown in Fig. 11(a). This is due to the internal stress and defects in the corrosion layer. ${ }^{40)}$ These cracks act as the paths for water and oxygen to reach the underlying layer, ${ }^{40)}$ resulting in linear growth of the tarnish layer.

Reduced sulfur species play two roles in the early stage of copper patination. One is lowering the $\mathrm{pH}$ of the surface electrolyte. While oxidized sulfur species do the same thing, the rate at which they lower the $\mathrm{pH}$ should be lower because the Henry's law coefficient of $\mathrm{H}_{2} \mathrm{~S}$ is one order of 
magnitude lower than that of $\mathrm{SO}_{2} \cdot{ }^{41)}$ The other role is the formation of $\mathrm{Cu}_{2} \mathrm{~S}$. As the $\mathrm{Cu}_{2} \mathrm{~S}$ thickness increases, cracks are generated. This promotes copper corrosion.

We should also consider the situation in which both oxidized and reduced sulfur species play roles in atmospheric copper corrosion. We do this using the volcanic area as an example. ${ }^{15)}$ 16) The corrosion products that formed on the copper plate exposed for 22 days in this area were cuprite and posnjakite, the same as for the urban, rural/coastal, and suburban areas, where sulfur mainly exists as oxidized species. However, as described previously, ${ }^{15), 16)}$ the evolution of the corrosion products differed. After 212 days of exposure in the volcanic area, the corrosion products identified by analysis of the XRD patterns were cuprite, posnjakite, brochantite, antlerite, and geerite $\left(\mathrm{Cu}_{8} \mathrm{~S}_{5}\right)$. When both $\mathrm{SO}_{2}$ and $\mathrm{H}_{2} \mathrm{~S}$ were found, there was faster formation of cupric ions on the surface, resulting in the formation of geerite instead of cuprous sulfide $\left(\mathrm{Cu}_{2} \mathrm{~S}\right)$.

\subsection{Role of chlorine in early stage of copper pati- nation}

The chlorine found on the copper originated from two sources: chlorine-containing gases and chlorine-containing particles. Hydrogen chloride $(\mathrm{HCl})$ and chlorine gas $\left(\mathrm{Cl}_{2}\right)$ are potential corrosive gases that contain chlorine. The outdoor concentration of $\mathrm{HCl}$ averages about $1 \mathrm{ppb}^{42)}$ The concentration of $\mathrm{Cl}_{2}$ is much lower. ${ }^{42)}$ This means that the contribution of $\mathrm{Cl}_{2}$ was negligible. We measured the outdoor $\mathrm{HCl}$ concentrations at two sites in Tokyo other than those in this study using a passive sampler. The average monthly concentrations were below the detection limit $\left.(<0.2 \mathrm{ppb}){ }^{43}\right)$ We conclude that the role played by chlorine-containing gases in atmospheric copper corrosion is negligible.

Sea-salt aerosol is a typical chlorine-containing substance. It is mainly composed of sodium chloride $(\mathrm{NaCl})$, which has a $\mathrm{CRH}$ of $75 \%{ }^{32}$ ) When it deposits on surface electrolyte, the $\mathrm{NaCl}$ dissolves in accordance with

$$
\mathrm{NaCl} \rightarrow \mathrm{Na}^{+}+\mathrm{Cl}^{-}
$$

if the $\mathrm{RH}$ of the atmosphere exceeds the CRH. As shown by the depth profile analysis, the peak position of chlorine in the GDOES depth profile differed from that of sodium. This confirms the dissolution of sodium chloride in the surface electrolyte.

As mentioned in the discussion of the XRD results, we did not find any chlorine-containing crystalline phase in the XRD patterns. There are two possible reasons for this absence : slow formation of chlorine-containing phases and insufficient chlorine accumulation on copper exposed for one month to form these phases. Feitknecht reported that cuprite formed in a solution with a small amount of $\mathrm{NaCl}$ $(0.001 \mathrm{M})$ while cuprite and basic copper chloride (atacamite) formed in one with a large amount of $\mathrm{NaCl}$ (1 M) ${ }^{44)} \mathrm{He}$ explained this findings using a pCl-pH diagram. We can thus explain the absence of chlorine-containing phases on copper in our studies as being due to the small amount of accumulated chlorine.

The chloride ions generated in accordance with equation (22) react with the cuprite on the copper surface and form copper chloride complex (equation (1)).32) The anodic and cathodic reactions described by equations (6) and (13), respectively, also proceed. Under these conditions, both the formation of cuprite described by equation (15) and the formation of $\mathrm{CuCl}$ (nantokite) occur. ${ }^{32}$ )

$$
\mathrm{Cu}^{+}+\mathrm{Cl}^{-} \rightarrow \mathrm{CuCl}
$$

A reversible reaction also occurs between nantokite and copper chloride complex. ${ }^{32}$

$$
\mathrm{CuCl}_{2}{ }^{-} \Leftrightarrow \mathrm{CuCl}+\mathrm{Cl}^{-}
$$

As shown in the XRD analysis, the cuprite formation was fairly fast. This indicates that cuprite formation proceeds even though the chloride ions are present in the surface electrolyte. As the exposure time increased, both the thickness of the cuprite and the amount of $\mathrm{Cl}^{-}$in the surface electrolyte increased. When the $\mathrm{Cl}^{-}$concentration became high, the initially formed cuprite was dissolved by $\mathrm{Cl}^{-}$in accordance with equation (1), forming $\mathrm{CuCl}_{2}{ }^{-}$. This cuprite dissolution may occur at the grain boundary of cuprite crystal. As a result, the $\mathrm{CuCl}_{2}{ }^{-}$and/or $\mathrm{Cl}^{-}$gradually penetrated the cuprite through the grain boundary. This changed the chloride depth profile, as shown in Fig. 13 (b). As previously reported, ${ }^{17)}$ the chlorine depth profile gradually changed and a pile up of the chlorine near the cuprite/copper interface was observed after one year of exposure. Nantokite was also observed after one year of exposure. ${ }^{17)}$ This indicates that the formation of nantokite is much slower than that of cuprite. The change in the chlorine depth profile also indicates that nantokite may form in the vicinity of the cuprite/copper interface, where copper dissolution mainly occurs. At the interface, the nantokite forms in accordance with equations (23) and (24).

There is another possible explanation for the change in the chlorine depth profile : the formation of a rough surface due to posnjakite formation. As described above, when oxidized sulfur is present, posnjakite forms. The growth of posnjakite crystals makes the surface rougher. The surface electrolyte gathers in the valleys with the ions. Chloride ions thus apparently penetrated the copper patina, as evidenced by the chlorine depth profile. However, this interpretation cannot account for the distribution of other elements such as nitrogen. As seen in Fig. 13(b), there was a difference in the depth profiles of nitrogen and chlorine. Assuming that the above mechanism is true, the nitrogen depth profile must be the same as the chlorine depth profile. We think both the dissolution of cuprite by $\mathrm{Cl}^{-}$and the effect of surface roughness played a role in changing the chlorine depth profile.

In short, accumulation of chlorine (mainly from sea-salt aerosol) results in the formation of copper chloride complex $\left(\mathrm{CuCl}_{2}^{-}\right)$. This changes the chlorine depth profile. The penetrating $\mathrm{CuCl}_{2}{ }^{-}$and/or $\mathrm{Cl}^{-}$form nantokite when their concentrations are high enough, although this could not be observed on the copper exposed for one month in 
this study.

\section{Conclusion}

The patinas that formed on the copper plates exposed for one month in urban, rural/coastal, hot springs, suburban, and volcanic areas were characterized by XRD, XRF, XPS, SEM, and GDOES to get a better understanding of the early stage of copper patination. The XRD patterns revealed that cuprite and posnjakite formed on the copper exposed in urban, rural/coastal, suburban, and volcanic areas. This is the first report of posnjakite forming on copper exposed for one month in benign environments. The XRD pattern revealed only cuprite on the copper exposed in the hot springs area although copper sulfide $\left(\mathrm{Cu}_{2} \mathrm{~S}\right)$ was found in the cathodic reduction curve. This indicates the formation of a non-crystalline sulfide phase. The sulfur $2 p$ XPS spectra of copper exposed in the urban, rural/coastal, and volcanic areas mainly showed the sulfate component, whereas that of copper exposed in the hot springs area showed both sulfide and sulfate components. The former reflected the formation of posnjakite ; the latter indicated the oxidation of sulfide during exposure. In contrast, the chlorine $2 \mathrm{p}$ XPS spectra revealed that the chlorine existed as chloride. The SEM observation revealed that the surface morphologies differed between exposure sites. Depth profiling analysis by GDOES revealed a difference in the distributions of sulfur and chlorine in the early stage of copper patination. The sulfur was in the upper part of the patina, whereas the chlorine penetrated it. The roles of sulfur and chlorine in the early stage of copper patination were also investigated. Oxidized sulfur species such as $\mathrm{SO}_{2}$ and $\left(\mathrm{NH}_{4}\right)_{2} \mathrm{SO}_{4}$ lower the $\mathrm{pH}$ of the surface electrolyte, which accelerates the dissolution of cuprite. They also form posnjakite, which roughens the surface. Reduced sulfur species such as $\mathrm{H}_{2} \mathrm{~S}$ and $\mathrm{COS}$ lower the $\mathrm{pH}$ of the surface electrolyte. They also form $\mathrm{Cu}_{2} \mathrm{~S}$; however, it is not crystalline but non-crystalline phase in the early stage. The role of chlorine mainly from sea-salt aerosol is the formation of copper chloride complex $\left(\mathrm{CuCl}_{2}^{-}\right)$. This changes the chlorine depth profile. In the later stage, the penetrating $\mathrm{CuCl}_{2}{ }^{-}$and/or $\mathrm{Cl}^{-}$form nantokite.

\section{References}

1) R. E. Lobnig, R. P. Frankenthal, C. A. Jankoski, D. J. Siconolfi, J. D. Sinclair, M. Unger and M. Stratmann, in Corrosion and Reliability of Electronic Materials and Devices, $\mathrm{R}$. B. Comizzoli, R. P. Frankenthal and J. D. Sinclair, Editors, PV99-29, p.97, The Electrochemical Society Proceedings Series, Pennington, NJ (1999).

2) Y. Ishikawa and T. Ozaki, in Corrosion and Reliability of Electronic Materials and Devices, R. B. Comizzoli, R. P. Frankenthal and J. D. Sinclair, Editors, PV99-29, p.59, The Electrochemical Society Proceedings Series, Pennington, NJ (1999)

3) R. B. Comizzoli, R. P. Frankenthal, P. C. Milner and J. D. Sinclair, Science, 234, 340 (1986)

4) B. I. Rickett and J. H. Payer, J. Electrochem. Soc., 142, 3713 (1995).

5) R. Ericsson and T. Sydberger, Werkst. Korros., 28, 755
(1977).

6) D. Persson and C. Leygraf, J. Electrochem. Soc., 142, 1459 (1995).

7) R. E. Lobnig, R. P. Frankenthal, D. J. Siconolfi and J. D. Sinclair, J. Electrochem. Soc., 140, 1902 (1993).

8) R. E. Lobnig, R. P. Frankenthal, D. J. Siconolfi, J. D. Sinclair and M. Stratmann, J. Electrochem. Soc., 141, 2935 (1994).

9) K. Nassau, P. K. Gallagher, A. E. Muller and T. E. Graedel, Corros. Sci., 27, 669 (1987).

10) J. Nairn, K. FitzGerald and A. Atrens, in Proceedings of the Australasian Corrosion Association Conference, Paper 59 (1994).

11) M. Watanabe, M. Tomita and T. Ichino, J. Electrochem. Soc., 148, B522 (2001).

12) M. Watanabe, M. Tomita and T. Ichino, J. Electrochem. Soc., 149, B97 (2002)

13) M. Watanabe, Y. Higashi and T. Ichino, J. Electrochem. Soc., 150, B37 (2003)

14) M. Watanabe, Y. Higashi and T. Tanaka, Corros. Sci., 45, 1439 (2003)

15) M. Watanabe, A. Hokazono, T. Handa, T. Ichino and N. Kuwaki, Corros. Sci., 48, 3759 (2006).

16) M. Watanabe, T. Handa, T. Ichino and N. Kuwaki, Paper 804 presented at 2006 Joint International Meeting, The Electrochemical Society, Cancun, Mexico (2006).

17) M. Watanabe, E. Toyoda, T. Handa, T. Ichino, N. Kuwaki, Y. Higashi and T. Tanaka, Corros. Sci., 49, 766 (2007).

18) I. Odnevall and C. Leygraf, J. Electrochem. Soc., 142, 3682 (1995).

19) M. Watanabe and T. Ichino, Zairyo-to-Kankyo, 51, 17 (2002).

20) I. T. E. Fonseca, R. Picciochi, M. H. Mendonca and A. C. Ramos, Corros. Sci., 46, 547 (2004).

21) S. K. Chawla, N. Sankarraman and J. H. Payer, J. Electron Spectrosc. Relat. Phenom., 61, 1 (1992).

22) S. K. Chawla, B. I. Rickett, N. Sankarraman and J. H. Payer, Corros. Sci., 33, 1617 (1992).

23) T. Robert, M. Bartell and G. Offergeld, Surf. Sci., 33, 123 (1972).

24) E. Cano, M. F. Ropez, J. Simancas and J. M. Bastidas, J. Electrochem. Soc., 148, E26 (2001).

25) T. E. Graedel, J. P. Franey, G. W. Kammlott and J. M. Vandenberg, J. Electrochem. Soc., 134, 1632 (1987).

26) M. Forslund and C. Leygraf, J. Electrochem. Soc., 144, 113 (1997).

27) S. Jouen, M. Jean and B. Hannoyer, Surf. Interface Anal., 30, 145 (2000).

28) R. B. Comizzoli, R. P. Frankenthal, R. E. Lobnig, G. A. Peins, L. A. Psota-Kelty, D. J. Siconolfi and J. D. Sinclair, Electrochem. Soc. Interface, 2 [3] 26 (1993).

29) T. Aastrup, M. Wadsak, M. Schreiner and C. Leygraf, Corros. Sci. 42, 957 (2000).

30) T. E. Graedel, J. P. Franey and G. W. Kammlott, Corros. Sci., 23, 1141 (1983)

31) J. P. Franey and M. E. Davis, Corros. Sci., 27, 659 (1987).

32) H. Strandberg and L.-G. Johansson, J. Electrochem. Soc., 145, 1093 (1998).

33) M. Watanabe, E. Toyoda, T. Handa and N. Kuwaki, Bosei Kanri (Rust Prev. Control) , 51, 87 (2007).

34) M. Watanabe, H. Ando, T. Handa, T. Ichino and N. Kuwaki, Zairyo-to-Kankyo, 56, 10 (2007).

35) C. Leygraf and T. E. Graedel, "Atmospheric Corrosion”, p.277, The Electrochemical Society Series, Wiley Interscience, New York (2000).

36) J. D. Sinclair, L. A. Psota-Kelty, C. J. Weschler and H. C. Shields, J. Electrochem. Soc., 137, 1200 (1990).

37) M. Watanabe and T. Ichino, Proceedings of the 42nd Annual Meeting of the Japan Society for Atmospheric Environment, p.461, Japan Society for Atmospheric Environment (2001).

38) M. Watanabe and T. Ichino, Zairyo-to-Kankyo, 51, 60 (2002).

39) T. E. Graedel, J. P. Franey, G. J. Gualtieri, G. W. Kammlott and D. L. Malm, Corros. Sci., 25, 1163 (1985).

40) M. Reid, J. Punch, C. Ryan, L. F. Garfias, S. Belochapkine, J. P. Franey, G. E. Derkits, Jr. and W. D. Reents, Jr., J. Electrochem. Soc., 154, C209 (2007).

41) C. Leygraf and T. E. Graedel, "Atmospheric Corrosion”, p. 
111, The Electrochemical Society Series, Wiley Interscience, New York (2000).

42) D. W. Rice, R. J. Cappell, P. B. P. Phipps and P. Peterson, "Atmospheric Corrosion", W. H. Ailor Ed., p.651, WileyInterscience (1982)
43) M. Watanabe, unpublished work.

44) W. Feitknecht, Chem. Ind., 1102, Sept 5 (1959).

(Manuscript received April 1, 2008; in final form December 19, 2008)

\section{要 旨}

大気中における銅の初期段階の腐食挙動を都市部, 田園/海岸地域, 温泉地域, 郊外地域及び火山地域 において銅板を 1 力月暴露することにより調べた。暴露実験は夏季あるいは秋季に開始した。 1 力月間の 暴露により生成した銅腐食生成物を X 線回折, 蛍光 X 線分析法, X 線光電子分光法 (XPS), 走査型電子顕 微鏡及びグロー放電発光分光法 (GDOES) により評価した．温泉地域に暴露した銅板を除くすべての銅板 の X 線回折パターンは亜酸化銅及びポスンジャカイトの生成を示していた．郊外地域のようなマイルドな 環境でもポスンジャカイトが生成することを見いだした。温泉地域に暴露した銅板の場合，カソード還元 曲線には硫化銅の還元に由来するプラトーが観測されたが，X 線回折パターンは亜酸化銅のみの生成を示 していた．都市部, 田園/海岸地域及び火山地域に暴露した銅板表面の硫黄 $2 \mathrm{p}$ 領域の XPS スペクトルは 主として硫酸イオン由来のピークを示したが，温泉地域に暴露した銅板では硫化物イオン及び硫酸イオン 由来のピークを示した．前者はポスンジャカイトの生成を，後者は暴露中の硫化物の酸化を反映している ものと考えられる。一方，塩素 $2 \mathrm{p}$ 領域の XPS スペクトルはどの暴露地域においても塩化物イオンとして 存在することを示唆していた。走査型電子顕微鏡による表面形態観察の結果，暴露地域ごとに表面形態が 異なることが明らかとなった. GDOES による元素の深さ方向分析により銅の大気腐食の初期段階におい て腐食生成物中における硫黄と塩素の分布形態は異なることを明らかにした。硫黄は腐食生成物の外層側 に局在し，塩素は腐食生成物内部に侵入していた。硫黄の影響を酸化性硫黄と還元性硫黄に分類して考察 した。酸化性硫黄は表面の吸着水層の $\mathrm{pH}$ を低下させ，覀酸化銅の溶解を促進する。また，酸化性硫黄は 銅との反応によりポスンジャカイトを形成し，その生成の結果，表面は粗くなる。還元性硫黄も酸化性硫 黄と同様に表面の吸着水層の $\mathrm{pH}$ を低下させ，硫化銅を形成する．塩素は亜酸化銅を溶解して塩化銅錯体 を形成する。その結果，腐食生成物内部に侵入するため，塩素の深さ方向分布が変化する.

キーワード＼cjkstart銅，大気腐食，物理分析，硫黄，塩素 